\title{
Heat capacity and thermodynamic functions of $\gamma-\mathrm{Al}_{2} \mathrm{O}_{3}$
}

Jason J. Calvin, Megan Asplund, Ying Zhang, Baiyu Huang, and Brian F. Woodfield*

Department of Chemistry and Biochemistry, Brigham Young University, Provo, Utah 84602, U.S.A.

*Corresponding author. Tel.: +1 801422 2093; fax: +1 8014220153

Email address: brian_woodfield@byu.edu (B. F. Woodfield) 


\begin{abstract}
Alumina $\left(\mathrm{Al}_{2} \mathrm{O}_{3}\right)$ can be synthesized with a variety of crystalline structures, each with unique physical properties. Although the corundum phase $\left(\alpha-\mathrm{Al}_{2} \mathrm{O}_{3}\right)$ has been well studied, the other phases of alumina have had limited attention over the years. One of the low-density phases of alumina, $\gamma-\mathrm{Al}_{2} \mathrm{O}_{3}$, is important in a variety of technical applications, largely because of its large surface area, pore volume, and high thermal stability when compared to mesoporous silicas. The mesoporous structure of $\gamma-\mathrm{Al}_{2} \mathrm{O}_{3}$ causes it to be hygroscopic, and samples that are calcined at different temperatures can have widely varying amounts of water adsorbed to their surfaces as well as subtle changes in structure. We have measured the constant pressure heat capacities of four $\gamma-\mathrm{Al}_{2} \mathrm{O}_{3}$ samples that were calcined at $(300,600,900$, and 1100$){ }^{\circ} \mathrm{C}$ and have the chemical formulas $\mathrm{Al}_{2} \mathrm{O}_{3} \cdot 1.540 \mathrm{H}_{2} \mathrm{O}, \mathrm{Al}_{2} \mathrm{O}_{3} \cdot 0.811 \mathrm{H}_{2} \mathrm{O}, \mathrm{Al}_{2} \mathrm{O}_{3} \cdot 0.537 \mathrm{H}_{2} \mathrm{O}$, and $\mathrm{Al}_{2} \mathrm{O}_{3} \cdot 0.204 \mathrm{H}_{2} \mathrm{O}$, respectively. Molar heat capacities were measured from 1.8 to $300 \mathrm{~K}$ using a Quantum Design Physical Property Measurement System (PPMS), and the data was fit to a sum of theoretical functions below $15 \mathrm{~K}$, orthogonal polynomials from $10 \mathrm{~K}$ to $60 \mathrm{~K}$, and a combination of Debye and Einstein functions above $50 \mathrm{~K}$. These fits were then used to generate $C_{p, m}{ }^{\circ}, \Delta_{0}{ }^{\mathrm{T}} S_{\mathrm{m}}{ }^{\circ}, \Delta_{0}{ }^{\mathrm{T}} H_{\mathrm{m}}{ }^{\circ}$, and $\Phi_{\mathrm{m}}{ }^{\circ}$ values at smoothed temperatures from $0 \mathrm{~K}$ to $300 \mathrm{~K}$ for all samples. The differences in the thermodynamic functions for the samples is attributed to the differing amounts of water adsorbed to the surfaces and the corresponding change in the strength of water interactions with the surface.
\end{abstract}

KEYWORDS: $\gamma-\mathrm{Al}_{2} \mathrm{O}_{3}$, Heat Capacity, Thermodynamic properties 


\section{Introduction}

The physical properties of alumina make it a versatile material with a wide variety of applications, such as the production of aluminum metal, abrasion protection, as an abrasive, in catalytic supports, and as a thermal conductor or insulator depending on the structure [1-6]. Alumina can be found virtually everywhere as it almost instantly forms when aluminum metal is in contact with oxygen [7]. This thin covering of aluminum oxide passivates aluminum and gives aluminum its resistance to corrosion [8]. Often, manufacturers wishing to give their aluminum products increased protection will thicken the layer of aluminum oxide via anodizing [9].

Alumina's great versatility arises primarily from its structure. It has at least fifteen different phases (alpha, gamma, delta, kappa, etc.), but each phase has a distinct physical structure with a different set of properties [10-14]. One of the most common forms of alumina is $\alpha-\mathrm{Al}_{2} \mathrm{O}_{3}$, also known as corundum or sapphire. Another common phase of alumina, $\gamma-\mathrm{Al}_{2} \mathrm{O}_{3}$, is valuable in the field of catalysis because of its porous structure and excellent thermal stability [15-17]. This phase of alumina generally has large surface areas ranging from (160 to 400$) \mathrm{m}^{2} \cdot \mathrm{g}^{-1}$ $[18,19]$, which is one of the factors that makes it significantly more hygroscopic than many of the other alumina counterparts [20].

The water that is adsorbed to the surface of $\gamma-\mathrm{Al}_{2} \mathrm{O}_{3}$ influences its properties appreciably. Investigations into the nature of the water-surface interactions in high-surface area materials have been reported previously for $\mathrm{TiO}_{2}$ anatase and rutile and for $\mathrm{SnO}_{2}$ cassiterite [21-24]. Essentially, these studies found water is adsorbed in layers, typically with a tighter bound "inner" layer of water and more loosely bound "outer" layers of water [21-24]. These adsorbed water layers can significantly affect the properties of the materials. The adsorbed water on these $\gamma-$ $\mathrm{Al}_{2} \mathrm{O}_{3}$ samples is thought to behave in a similar manner. After calcination at different 
temperatures, $\gamma-\mathrm{Al}_{2} \mathrm{O}_{3}$ samples possess different amounts of adsorbed water, which contributes to the differences in properties. In a previous study, it has been shown that the presence of adsorbed water on $\gamma-\mathrm{Al}_{2} \mathrm{O}_{3}$ stabilizes the materials [25].

Corundum has long been a reference material for calibrating or demonstrating the accuracy of heat capacity measurements [26]. Because of this, a significant number of thermodynamic measurements have been collected for $\alpha-\mathrm{Al}_{2} \mathrm{O}_{3}$ [27-34]. Some of the other phases of alumina have been characterized by heat capacity measurements, but to a lesser extent [35-37]. This data is important to those who wish to use $\gamma-\mathrm{Al}_{2} \mathrm{O}_{3}$ in technological and industrial processes and to understand the variance in the thermodynamic properties of $\gamma-\mathrm{Al}_{2} \mathrm{O}_{3}$ as a function of calcination temperature and water content $[38,39]$. In a previous paper, we compared the heat capacity and inelastic neutron scattering data for a series of $\gamma-\mathrm{Al}_{2} \mathrm{O}_{3}$ as a function of pore size but no thermodynamic functions were calculated [37]. In this paper, we present heat capacity data for a series of $\gamma-\mathrm{Al}_{2} \mathrm{O}_{3}$ samples calcined at different temperatures but prepared from a single aluminum alkoxide precursor synthesized using a solvent deficient precipitation method [18]. The focus is on studying the effect of calcination temperature and water content on the intrinsic thermodynamic properties of $\gamma-\mathrm{Al}_{2} \mathrm{O}_{3}$.

\section{Experimental}

\subsection{Sample preparation and Characterization}

Alumina samples were prepared using a method previously described by Huang et al using aluminum iso-propoxide $\left(\mathrm{Al}\left(\mathrm{OCH}\left(\mathrm{CH}_{3}\right) \mathrm{CH}_{3}\right)_{3}\right)$ purchased from Alfa Aesar [18]. In the final step of the synthesis, aliquots from a common boehmite precursor are calcined in a muffle furnace for two hours at different temperatures, $300^{\circ} \mathrm{C}, 600^{\circ} \mathrm{C}, 900^{\circ} \mathrm{C}$, or $1100^{\circ} \mathrm{C}$, respectively. Note that for these particular $\gamma-\mathrm{Al}_{2} \mathrm{O}_{3}$ samples, the transition to $\alpha-\mathrm{Al}_{2} \mathrm{O}_{3}$ begins at 
$1150{ }^{\circ} \mathrm{C}$ and is complete by $1200{ }^{\circ} \mathrm{C}$. These samples will be subsequently referred to as AIP (for aluminum iso-propoxide precursor) followed by the temperature at which they were calcined. For example, the sample that was calcined at $300^{\circ} \mathrm{C}$ will be referred to as AIP 300 .

To verify the structures of these aluminas, each sample was analyzed by powder X-ray diffraction (XRD) on a Panalytical X'Pert Pro X-ray diffractometer with $\mathrm{Cu}-\mathrm{K} \alpha$ radiation $(\lambda=$ $0.15418 \mathrm{~nm}$ ) at a scanning rate of $0.02^{\circ} \mathrm{s}^{-1}$ in the $2 \theta$ ranges from $10^{\circ}$ to $80^{\circ}$. A fixed power source was used $(40 \mathrm{kV}, 40 \mathrm{~mA})$. The XRD spectra are included in Figure 1, and these measurements confirmed that the samples are pure phase $\gamma-\mathrm{Al}_{2} \mathrm{O}_{3}$. Specific surface area was determined using the Brunauer-Emmett-Teller (BET) method, with a $\mathrm{P} / \mathrm{P}_{0}$ range between 0.05 and 0.2 using a Micromeretics TriStar 3000, and the pore size distribution is calculated using a Slit Pore Geometry (SPG) model [40]. The purity of these samples was verified by inductively coupled plasma optical emission spectrometry (ICP-OES). Further details on the characterization and synthesis of the samples can be found elsewhere [18], and a summary of this characterization data is included in Table 1.

As mentioned above, an important feature of these samples is the amount of water that has been adsorbed onto the surface of the aluminas. To accurately determine the effect of the tightly bound "inner" layers of water on these samples, each sample was first dried in an oven at $150^{\circ} \mathrm{C}$ for 24 hours to remove the "outer" layers of adsorbed water, as only this outer water would be liberated from the surface at this temperature, leaving the inner layers of water on the sample. Immediately after the samples were dried, they were stored in an argon atmosphere with less than $1 \mathrm{ppm} \mathrm{O}_{2}$ and $\mathrm{H}_{2} \mathrm{O}$ to prevent adsorption of additional water before they were measured. Each sample was then subjected to thermogravimetric analysis by a Netzsch STA 409PC. Approximately $20 \mathrm{mg}$ of sample was loaded into a platinum pan and heated from room 
temperature to $900^{\circ} \mathrm{C}$ with a ramp rate of $3^{\circ} \mathrm{C} \cdot \mathrm{min}^{-1}$ under a $20 \mathrm{~mL} \cdot \mathrm{min}^{-1}$ flow of helium gas. The measured mass of these samples was constant with increasing temperature by the end of the measurement, and the graphical data of the mass of these samples as a function of temperature is included in Figure 2. The calculated amount of water adsorbed to these samples is also included in Table 1.

\subsection{Calorimetric Measurements}

Constant pressure heat capacities were measured with a Quantum Design Physical Property Measurement System (PPMS) from (1.8-300) K. The powdered alumina samples were encased in copper foil (99.999\% Alfa Aesar) in order to improve the thermal conductivity of the samples. The method is described in more detail elsewhere [41, 42]. The pellets were attached to the sample platform by a small amount of Apiezon-N grease, and their heat capacity measured under high vacuum. The sample masses as well as the copper foil masses for the pellets are included in Table 2.

The heat capacity of the copper, as well as the contribution of the grease used to attach the samples to the sample platform in the PPMS, was subtracted from the total heat capacity that was measured. Any contribution to the heat capacity due to the sample holder or calorimeter was accounted for by addenda measurements prior to the sample measurements.

\section{Results}

The measured molar heat capacity values for the four $\gamma-\mathrm{Al}_{2} \mathrm{O}_{3}$ samples (AIP 300, AIP 600, AIP 900, and AIP 1100) are given separately in Tables 3, 4, 5, and 6 and summarized graphically in Figure 3. The inset in Figure 3 shows the heat capacity data below $T=10 \mathrm{~K}$. The heat capacities of these samples are smooth without any obvious anomalies or transitions, but the 
heat capacities do decrease as the calcination temperature increases, which corresponds to the decreasing amount of water on the sample.

\section{Discussion}

\subsection{Data Fitting}

In general terms, the heat capacity is a measure of the occupancy of the various energetic states of a material as a function of temperature [38]. Using theoretical functions to model heat capacity data, information about the electronic, vibrational, and magnetic properties of a sample can be deduced. Because individual contributions to the overall heat capacity of the sample are dependent on of temperature, we can separate the heat capacity data into three different temperature regions and fit the data in these regions using different sets of functions. At low and high temperatures, we use theoretical models to fit the data, and for temperatures in between we use a polynomial function to overlap with these regions.

The contributions to the heat capacity data in the low temperature region, below about $T$ $=15 \mathrm{~K}$, are mostly dominated by the lattice vibrations but electronic and magnetic contributions can also be important. The function used to model the lattice vibrations contains odd powers in temperature.

$$
C_{\text {Lat }}=\sum_{n=3,5,7, \ldots} B_{n} T^{n}
$$

A linear dependence on $T$, or $\gamma T$, is typically associated with an electronic contribution to the overall heat capacity; however, for insulating materials, such as these $\gamma-\mathrm{Al}_{2} \mathrm{O}_{3}$ samples, a linear term can be necessary due to defects in the lattice or oxygen vacancies $[30,41]$.

The data from the temperature region (10-60) K was fit to a polynomial function. The fitting region was chosen to overlap with the low temperature and high temperature fits and to fit the inflection point around $100 \mathrm{~K}$. The fits were of the form: 


$$
C_{\text {mid } T}=\sum_{n=0,1,2 \ldots 6} A_{n} T^{n}
$$

The high temperature data (above $50 \mathrm{~K}$ ) was fit to a sum of Debye and Einstein functions. These functions are often used to represent the lattice contribution for simple solids, and are of the form

$$
C_{\text {high } T}=m \cdot D\left(\frac{\Theta_{D}}{T}\right)+n \cdot E\left(\frac{\Theta_{E, 1}}{T}\right)+A_{1} \cdot T
$$

where $\mathrm{D}\left(\Theta_{D} / T\right)$, and $\mathrm{E}\left(\Theta_{E} / T\right)$ are the Debye and Einstein functions respectively, the variables $m, n, \Theta_{D}, \Theta_{E}$, and $A_{l}$ are all adjustable parameters, and $(m+n)$ should be approximately equal to the number of atoms in the formula unit. The linear term, $A_{1} \cdot T$, approximates for the conversion of $\mathrm{C}_{V, m}$ to $\mathrm{C}_{p, m}$.

The best parameters for each of these functions for the different samples, as well as the regions for which they are valid and the \%RMS of the fits, are given in Table 7 . Lines representing the fitting functions are also included in Figure 3. Plots of the deviations of the function from the measured data are given by Figures 4-7 and show that the deviations are generally random and are representative of the data.

\subsection{Thermodynamic Calculations}

Fits representing the data were used to generate the standard molar thermodynamic functions $C_{p, m}{ }^{\circ}, \Delta_{0}{ }^{\mathrm{T}} S_{\mathrm{m}}{ }^{\circ}, \Delta_{0}{ }^{\mathrm{T}} H_{\mathrm{m}}{ }^{\circ}$, and $\Phi_{\mathrm{m}}{ }^{\circ}$ at smoothed temperatures from 0 to $300 \mathrm{~K}$. These data sets are given in Tables 8, 9, 10, and 11 for AIP 300, AIP 600, AIP 900, and AIP 1100 respectively. The standard state molar entropies are $93.350 \mathrm{~J} \cdot \mathrm{K}^{-1} \mathrm{~mol}^{-1}, 78.908 \mathrm{~J} \cdot \mathrm{K}^{-1} \mathrm{~mol}^{-1}$, 69.765 $\mathrm{J} \cdot \mathrm{K}^{-1} \mathrm{~mol}^{-1}$, and 61.201 $\mathrm{J} \cdot \mathrm{K}^{-1} \mathrm{~mol}^{-1}$ for AIP 300, AIP 600, AIP 900, and AIP 1100 respectively. 
As expected, the molar entropies of the samples decrease as the calcination temperature increases and the water content is reduced. As a comparison, the standard state molar entropy of $\alpha-\mathrm{Al}_{2} \mathrm{O}_{3}$ is $50.950 \mathrm{~J} \cdot \mathrm{K}^{-1} \mathrm{~mol}^{-1}[35]$, which is significantly less than the standard state molar entropies of all of the $\gamma-\mathrm{Al}_{2} \mathrm{O}_{3}$ samples. This should be expected since $\gamma-\mathrm{Al}_{2} \mathrm{O}_{3}$ is considerably less dense than $\alpha-\mathrm{Al}_{2} \mathrm{O}_{3}$. However, another more relevant comparison would be to look at the entropies for the high-surface area $\mathrm{TiO}_{2}$ nanoparticles previously measured $[21,22]$ with similar amounts of adsorbed water. A sample of $\mathrm{TiO}_{2} \cdot 0.532 \mathrm{H}_{2} \mathrm{O}$ anatase has a standard state molar entropy of $66.072 \mathrm{~J} \cdot \mathrm{K}^{-1} \mathrm{~mol}^{-1}$, compared to a standard state molar entropy of $69.765 \mathrm{~J} \cdot \mathrm{K}^{-1} \mathrm{~mol}^{-1}$ for $\mathrm{Al}_{2} \mathrm{O}_{3} \cdot 0.537 \mathrm{H}_{2} \mathrm{O}$ (AIP 900). A sample of $\mathrm{TiO}_{2} \cdot 0.244 \mathrm{H}_{2} \mathrm{O}$ rutile nanoparticles has a standard molar entropy of $58.035 \mathrm{~J} \cdot \mathrm{K}^{-1} \mathrm{~mol}^{-1}$, compared to a standard state molar entropy of $61.201 \mathrm{~J} \cdot \mathrm{K}^{-1}$ $\mathrm{mol}^{-1}$ for $\mathrm{Al}_{2} \mathrm{O}_{3} \cdot 0.204 \mathrm{H}_{2} \mathrm{O}$ (AIP 1100). Other $\mathrm{TiO}_{2}$ nanoparticles measured previously did not have similar amounts of adsorbed water compared to AIP 300 and AIP 600.

These results show the importance of water on the surfaces of mesoporous materials and how the water is bonded. Previously, we have developed models to account for water adsorbed onto the surfaces of nanoparticles [21-24], however, in this instance the water is integral to the structure of these alumina samples, and the water can behave differently for the different samples. To illustrate this, the smoothed molar heat capacity values for the AIP 600, AIP 900, and AIP 1100 found in Tables 9, 10, and 11, respectively, were individually subtracted from the smoothed heat capacity values of AIP 300 found in Table 8, since the AIP 600, 900, and 1100 samples had less water adsorbed to their surfaces than AIP 300. Similarly, the smoothed heat capacity values for AIP 900 and AIP 1100 were subtracted from the smoothed heat capacity values for AIP 600, and finally the smoothed heat capacity values for AIP 1100 was subtracted from the smoothed heat capacity values for AIP 900. The difference in water content for each 
subtraction was used to determine the molar heat capacity of the water adsorbed to the surfaces of the samples, and thus the resulting heat capacity differences, to a great extent, should represent the behavior of water on the surfaces of the alumina surfaces. These calculated values for the molar heat capacity of the adsorbed water on the surfaces, as well as the molar heat capacity of hexagonal ice for a comparison [43], are plotted in Figure 8.

If the differences in heat capacities were caused only by there being more water on some of the samples, the resulting molar heat capacity of the water from each subtraction should be nearly the same. However, there are large differences in the calculated molar heat capacity of the water, which indicates that the water that is bonded to the surface behaves differently on each sample. What is even more interesting is that the molar heat capacities of the subtracted water do not have any obvious trends relative to each other, that is, water that comes off at higher temperatures is not necessarily more tightly bound than water coming off at a lower temperature. It is true that the water heat capacities for all of the adsorbed water are below the heat capacity of hexagonal ice [43], indicating that the adsorbed water is more tightly bonded and likely contributes to the thermal stability of these catalyst support materials [25]. However, the behavior of the water at different calcination temperatures is not systematic, thus suggesting that the $\gamma-\mathrm{Al}_{2} \mathrm{O}_{3}$ samples calcined at different temperatures are unique.

In a previous study we conducted, the heat capacities were compared between four $\gamma$ $\mathrm{Al}_{2} \mathrm{O}_{3}$ samples as a function of pore size [37]. These samples were prepared using a variety of methods and were all calcined at $700{ }^{\circ} \mathrm{C}$, and they had molar water contents between 0.48 and 0.69 moles of water per mole of alumina. The values of the constant pressure heat capacity at $298.15 \mathrm{~K}$ were $112.156 \mathrm{~J} \cdot \mathrm{K}^{-1} \mathrm{~mol}^{-1}$ for $\mathrm{Al}_{2} \mathrm{O}_{3} \cdot 0.69 \mathrm{H}_{2} \mathrm{O}, 122.461 \mathrm{~J} \cdot \mathrm{K}^{-1} \mathrm{~mol}^{-1}$ for $\mathrm{Al}_{2} \mathrm{O}_{3} \cdot 0.59 \mathrm{H}_{2} \mathrm{O}$, 129.982 $\mathrm{J} \cdot \mathrm{K}^{-1} \mathrm{~mol}^{-1}$ for $\mathrm{Al}_{2} \mathrm{O}_{3} \cdot 0.50 \mathrm{H}_{2} \mathrm{O}$, and $112.938 \mathrm{~J} \cdot \mathrm{K}^{-1} \mathrm{~mol}^{-1}$ for $\mathrm{Al}_{2} \mathrm{O}_{3} \cdot 0.48 \mathrm{H}_{2} \mathrm{O}$, which were 
all larger than the value of the constant pressure heat capacity of $95.056 \mathrm{~J} \cdot \mathrm{K}^{-1} \mathrm{~mol}^{-1}$ for $\mathrm{Al}_{2} \mathrm{O}_{3} \cdot 0.537 \mathrm{H}_{2} \mathrm{O}$ (AIP 900) at $298.15 \mathrm{~K}$. Although the samples in that study had a similar amount of water adsorbed to their surfaces as AIP 900, differences in the calcination temperature or pore sizes may explain the difference in heat capacities. This study claimed that neither the pore diameter nor the water content influenced the thermodynamic properties of the materials, however as we have seen in this study that the water content does have an appreciable effect.

\section{Conclusion}

The heat capacities of several $\gamma-\mathrm{Al}_{2} \mathrm{O}_{3}$ samples were measured from $1.8 \mathrm{~K}$ to $300 \mathrm{~K}$. Fits

of each data set were used to generate $C_{p, m}{ }^{\circ}, \Delta_{0}{ }^{\mathrm{T}} S_{\mathrm{m}}{ }^{\circ}, \Delta_{0}{ }^{\mathrm{T}} H_{\mathrm{m}}{ }^{\circ}$, and $\Phi_{\mathrm{m}}{ }^{\circ}$ values at smoothed temperatures from 0 to $300 \mathrm{~K}$. It was shown that the differences in the heat capacities of these materials are due to the variability of the water bound to the surfaces as a function of calcination temperature. This makes each of these samples a unique material, and attempting to subtract the contributions of the water is nontrivial.

\section{Acknowledgements}

This work was financially supported by a grant from the U.S. Department of Energy under grant DE-SC0016446. 


\section{References}

[1] J.P. Murray, Solar Energy 66, 133 (1999).

[2] G. Hass, Journal of the Optical Society of America 39, 532 (1949).

[3] J. Su, J. Du, L. Ma, Z. Zhang, R. Kang, Journal of Semiconductors 33, 106003 (2012).

[4] H. Adkins, L. M. Richards, and J. W. Davis, Journal of the American Chemical Society 63, $1320(1941)$.

[5] R. Berman, Proceedings of the Physical Society Section A. 65, 1029 (1952).

[6] M. Munro, Journal of the American Ceramic Society 80, 1919 (2005).

[7] W. H. Krueger and S. R. Pollack, Surface Science 30, 263 (1972).

[8] F. Keller, M. S. Hunter, and D. L. Robinson, Journal of the Electrochemical. Society 100, $411(1953)$.

[9] Y. Huang, H. Shih, H. Huang, J. Daugherty, S. Wu, S. Ramanathan, C. Chang, and F. Mansfeld, Corrosion Science 50, 3569 (2008).

[10] S.J. Smith, S. Amin, B.F. Woodfield, J. Boerio-Goates, B.J. Campbell, Inorganic Chemistry 52, 4411 (2013).

[11] I. Levin, D. Brandon, Journal of the American Ceramic Society 81, 1995 (2005).

[12] A. Dauger, D. Fargeot, and J. P. Laval, MRS Proceedings 21, (1983).

[13] Z. Łodziana and K. Parliński, Physical Review B 67, 174106 (2003).

[14] A. Boumaza, L. Favaro, J. Lédion, G. Sattonnay, J. B. Brubach, P. Berthet, A. M. Huntz, P. Roy, and R. Tétot, Journal of Solid State Chemistry 182, 1171 (2009).

[15] D. L. Hoang, S. H. Chan, and O. L. Ding, Chemical Engineering Journal 112, 1 (2005).

[16] N. K. Nag, Catalysis Letters 24, 37 (1994).

[17] R. S. Schiffino, and R. P. Merrill, The Journal of Physical Chemistry 97, 6425 (1993). 
[18] B. Huang, C.H. Bartholomew, and B.F. Woodfield, Microporous Mesoporous Materials 177, 37 (2013).

[19] C. Márquez- Alvarez, N. Žilková, J. Pérez- Pariente, and J. Čejka, Catalysis Reviews 50, 222 (2008).

[20] D. S. Maciver, H.H. Tobin, and R.T. Barth, Journal of Catalysis 2, 485 (1963).

[21] J. M. Schliesser, S. J. Smith, G. Li, L. Li, T. F. Walker, T. Parry, J. Boerio-Goates, B. F. Woodfield, The Journal of Chemical Thermodynamics. 81, 298 (2015).

[22] J. M. Schliesser, S. J. Smith, G. Li, L. Li, T. F. Walker, T. Parry, J. Boerio-Goates, B. F. Woodfield, The Journal of Chemical Thermodynamics 81, 311 (2015).

[23] J. Boerio-Goates, G. Li, L. Li, T. F. Walker, T. Parry, and B. F. Woodfield, Nano Letters 6, 750 (2006).

[24] E. C. Spencer, N. L. Ross, S. F. Parker, A. I. Kolesnikov, B. F. Woodfield, K. Woodfield, M. Rytting, J. Boerio-Goates, A. Navrotksy, The Journal of Physical Chemistry C 115, 21105 (2011).

[25] J.M.M., A. Navrotsky, A.J. Perrotta, Journal of Physical Chemistry B 101, 603 (1997).

[26] D. C. Ginnings and G.T. Furukawa, Journal of the American Chemical Society 75, 522 (1953).

[27] D. A. Ditmars, S. Ishihara, S.S. Chang, G. Bernstein, and E.D. West, Journal of Research of the National Bureau of Standards 87, 159 (1982).

[28] D. G. Archer, Journal of Physical and Chemical Reference Data 22, 1441 (1993).

[29] L. Wang, Z. Tan, S. Meng, D. Liang, and G. Li, Journal of Nanoparticle Research 3, 483 (2001). 
[30] A. J. Leadbetter, Journal of Physics C: Solid State Physics 1, 1481 (1968).

[31] Z.-C. Tan, Q. Shi, B.-P. Liu, and H.-T. Zhang, Journal of Thermal Analysis and Calorimetry 92, 367 (2008).

[32] A. Inaba, The Journal of Chemical Thermodynamics 15, 1137 (1983).

[33] R. Q. Fugate, Journal of Applied Physics 40, 3034 (1969).

[34] B. E. Walker, J. A. Grand, and R. R. Miller, The Journal of Physical Chemistry 60, 231 (1956).

[35] M. Chase, The Journal of Physical Chemistry Reference Data, Monogaph 9, (1998).

[36] Q. Chen, W. Zeng, X. Chen, S. Gu, G. Yang, H. Zhou, Z. Yin, Thermochimica Acta, 253, 33 (1995).

[37] E. C. Spencer, B. Huang, S. F Parker, A. I. Kolesnikov, N. L. Ross, B. F. Woodfield, The Journal of Chemical Physics 139, 244705 (2013).

[38] E. S. R. Gopal, Specific heats at low temperatures (Plenum Press New York, 1966), Vol. 227.

[39] J. B. Ott and J. Boerio-Goates, Chemical Thermodynamics: Advanced Applications: Advanced Applications (Academic Press, 2000), Vol. 2.

[40] B. Huang, C.H. Bartholomew, and B.F. Woodfield, Microporous and Mesoporous Materials 184, 112 (2014).

[41] Q. Shi, C. L. Snow, J. Boerio-Goates, B. F. Woodfield, The Journal of Chemical Thermodynamics 42, 1107 (2010).

[42] Q. Shi, J. Boerio-Goates, B. F. Woodfield, The Journal of Chemical Thermodynamics 43, 1263 (2011). 
[43] J. Boerio-Goates, G. Li, L. Li, T.F. Walker, T. Parry, B.F. Woodfield, Nano Letters 6, 750 (2006). 
Table 1. A summary of the masses and characterization data for each of the four $\gamma-\mathrm{Al}_{2} \mathrm{O}_{3}$ samples reported in this paper. Chemical purity for all samples was determined using ICP-OES. The estimated standard uncertainty in the water content is $u=0.01 \mathrm{~mol} \mathrm{H} \mathrm{H}_{2} \mathrm{O} \cdot \mathrm{mol}^{-1}$.

\begin{tabular}{cccccc}
\hline Sample & $\begin{array}{c}\text { Water Content/ } \\
\left(\mathrm{mol} \mathrm{H} \mathrm{O}_{2} \cdot \mathrm{mol}^{-1}\right)\end{array}$ & $\begin{array}{c}\text { Mass } \\
\text { Fraction } \\
\text { Purity }\end{array}$ & $\begin{array}{c}\text { Surface Area/ } \\
\left(\mathrm{m}^{2} \cdot \mathrm{g}^{-1}\right)\end{array}$ & $\begin{array}{c}\text { Pore } \\
\text { Volume/ } \\
\left(\mathrm{cm}^{3} \cdot \mathrm{g}^{-1}\right)\end{array}$ & $\begin{array}{c}\text { Pore Diameter/ } \\
(\mathrm{nm})\end{array}$ \\
\hline AIP 300 & 1.540 & $>0.999$ & 369 & 1.35 & 12.5 \\
AIP 600 & 0.811 & $>0.999$ & 309 & 1.49 & 13.1 \\
AIP 900 & 0.537 & $>0.999$ & 179 & 1.20 & 18.2 \\
AIP 1100 & 0.204 & $>0.999$ & 97 & 0.43 & 19.9 \\
\hline
\end{tabular}


Table 2. Details of the PPMS calorimetric measurements including pressures $(p)$, sample mass, $\left(M_{s}\right)$, molar mass $(M)$, and copper mass $\left(M_{C u}\right)$. The estimated standard uncertainties in the masses $M_{s, C u}$ and pressure $p$ are $u\left(M_{s, C u}\right)=0.06 \mathrm{mg}$ and $u(p)=0.1 \mathrm{mPa}$.

\begin{tabular}{lllll}
\hline & $\mathrm{Al}_{2} \mathrm{O}_{3} \cdot 1.540 \mathrm{H}_{2} \mathrm{O}$ & $\mathrm{Al}_{2} \mathrm{O}_{3} \cdot 0.811 \mathrm{H}_{2} \mathrm{O}$ & $\mathrm{Al}_{2} \mathrm{O}_{3} \cdot 0.537 \mathrm{H}_{2} \mathrm{O}$ & $\mathrm{Al}_{2} \mathrm{O}_{3} \cdot 0.204 \mathrm{H}_{2} \mathrm{O}$ \\
\hline$p / \mathrm{mPa}$ & 1.2 & 1.2 & 1.2 & 1.2 \\
$M_{s} / \mathrm{mg}$ & 14.62 & 13.16 & 18.50 & 21.78 \\
$M / \mathrm{g} \cdot \mathrm{mol}^{-1}$ & 129.705 & 116.572 & 111.635 & 105.636 \\
$M_{C u} / \mathrm{mg}$ & 34.80 & 30.60 & 32.80 & 28.02 \\
\hline
\end{tabular}


Table 3. Measured molar heat capacity values at constant pressure for $\gamma$-alumina $\mathrm{Al}_{2} \mathrm{O}_{3} \cdot 1.540 \mathrm{H}_{2} \mathrm{O} . M=129.70 \mathrm{~g} \cdot \mathrm{mole}^{-1}$. Measurements were performed using a Quantum Design Physical Properties Measurement System (PPMS) with a standard uncertainty of $2 \% C_{p, \mathrm{~m}}$ below about $T=10 \mathrm{~K}$ and $1 \% C_{p, \mathrm{~m}}$ from $T=(10$ to 300$) \mathrm{K}$. The standard uncertainty in temperature is about $4 \mathrm{mK}$.

\begin{tabular}{|c|c|c|c|c|c|}
\hline$T / \mathrm{K}$ & $C_{p, \mathrm{~m}} / \mathrm{J} \cdot \mathrm{K}^{-1} \cdot \mathrm{mol}^{-1}$ & $T / \mathrm{K}$ & $C_{p, \mathrm{~m}} / \mathrm{J} \cdot \mathrm{K}^{-1} \cdot \mathrm{mol}^{-1}$ & $T / \mathrm{K}$ & $C_{p, \mathrm{~m}} / \mathrm{J} \cdot \mathrm{K}^{-1} \cdot \mathrm{mol}^{-1}$ \\
\hline 1.8294 & $4.1433 \cdot 10^{-3}$ & 8.0688 & 0.077556 & 77.383 & 16.938 \\
\hline 1.9162 & $4.7529 \cdot 10^{-3}$ & 8.4197 & 0.087442 & 84.563 & 20.589 \\
\hline 2.0005 & $4.9720 \cdot 10^{-3}$ & 8.7887 & 0.094787 & 92.406 & 24.672 \\
\hline 2.0899 & $5.2748 \cdot 10^{-3}$ & 9.1709 & 0.11111 & 100.97 & 29.080 \\
\hline 2.1832 & $5.8342 \cdot 10^{-3}$ & 9.5695 & 0.12087 & 111.08 & 34.630 \\
\hline 2.2821 & $6.2464 \cdot 10^{-3}$ & 9.9836 & 0.12845 & 121.14 & 40.459 \\
\hline 2.4044 & $7.3068 \cdot 10^{-3}$ & 10.396 & 0.14252 & 131.20 & 46.301 \\
\hline 2.5469 & $7.7452 \cdot 10^{-3}$ & 10.788 & 0.15649 & 141.31 & 52.003 \\
\hline 2.6535 & $8.4031 \cdot 10^{-3}$ & 11.252 & 0.17216 & 151.36 & 57.971 \\
\hline 2.7493 & $8.9085 \cdot 10^{-3}$ & 11.745 & 0.18830 & 161.48 & 63.704 \\
\hline 2.8985 & $9.3554 \cdot 10^{-3}$ & 12.266 & 0.21168 & 171.53 & 69.218 \\
\hline 3.0038 & 0.010628 & 12.812 & 0.23877 & 181.61 & 74.941 \\
\hline 3.1484 & 0.012256 & 13.379 & 0.26842 & 191.67 & 80.494 \\
\hline 3.2879 & 0.012813 & 13.965 & 0.30159 & 201.80 & 85.539 \\
\hline 3.4145 & 0.013231 & 14.593 & 0.33771 & 211.88 & 90.491 \\
\hline 3.5730 & 0.013675 & 15.233 & 0.37635 & 221.89 & 95.369 \\
\hline 3.7214 & 0.015139 & 15.737 & 0.40737 & 231.96 & 99.901 \\
\hline 3.8892 & 0.018018 & 17.215 & 0.51452 & 242.02 & 104.16 \\
\hline 4.0572 & 0.018222 & 18.799 & 0.63926 & 252.17 & 108.66 \\
\hline 4.2365 & 0.021759 & 20.512 & 0.79439 & 262.24 & 112.82 \\
\hline 4.4203 & 0.024047 & 22.453 & 0.98409 & 272.31 & 116.50 \\
\hline 4.6169 & 0.023935 & 24.515 & 1.1895 & 282.29 & 120.68 \\
\hline 4.8255 & 0.026114 & 26.765 & 1.5020 & 292.44 & 124.45 \\
\hline 5.0389 & 0.028609 & 29.235 & 1.8661 & 302.52 & 127.89 \\
\hline 5.2570 & 0.032515 & 31.937 & 2.3062 & & \\
\hline 5.4861 & 0.034030 & 34.891 & 2.8598 & & \\
\hline 5.7270 & 0.036533 & 38.112 & 3.5181 & & \\
\hline 5.9762 & 0.038023 & 41.638 & 4.3235 & & \\
\hline 6.2412 & 0.045085 & 45.487 & 5.3364 & & \\
\hline 6.5112 & 0.050237 & 49.701 & 6.3804 & & \\
\hline 6.7915 & 0.059069 & 54.300 & 7.8201 & & \\
\hline 7.0941 & 0.061698 & 59.326 & 9.5228 & & \\
\hline 7.4047 & 0.061290 & 64.818 & 11.546 & & \\
\hline 7.7280 & 0.070377 & 70.815 & 13.964 & & \\
\hline
\end{tabular}


Table 4. Measured molar heat capacity values at constant pressure for $\gamma$-alumina $\mathrm{Al}_{2} \mathrm{O}_{3} \cdot 0.811 \mathrm{H}_{2} \mathrm{O} \cdot M=116.57 \mathrm{~g} \cdot \mathrm{mole}^{-1}$. Measurements were performed using a Quantum Design Physical Properties Measurement System (PPMS) with a standard uncertainty of $2 \% C_{p, \mathrm{~m}}$ below about $T=10 \mathrm{~K}$ and $1 \% C_{p, \mathrm{~m}}$ from $T=(10$ to 300$) \mathrm{K}$. The standard uncertainty in temperature is about $4 \mathrm{mK}$.

\begin{tabular}{llllll}
\hline$T / \mathrm{K}$ & $C_{p, \mathrm{~m}} / \mathrm{J} \cdot \mathrm{K}^{-1} \cdot \mathrm{mol}^{-1}$ & $T / \mathrm{K}$ & $C_{p, \mathrm{~m}} / \mathrm{J} \cdot \mathrm{K}^{-1} \cdot \mathrm{mol}^{-1}$ & $T / \mathrm{K}$ & $C_{p, \mathrm{~m}} / \mathrm{J} \cdot \mathrm{K}^{-1} \cdot \mathrm{mol}^{-1}$ \\
\hline 1.8247 & $4.6306 \cdot 10^{-3}$ & 8.0453 & 0.061397 & 77.367 & 15.043 \\
1.9136 & $5.0994 \cdot 10^{-3}$ & 8.3917 & 0.058959 & 84.547 & 18.283 \\
1.9989 & $5.3532 \cdot 10^{-3}$ & 8.7628 & 0.074127 & 92.392 & 21.734 \\
2.0924 & $5.8546 \cdot 10^{-3}$ & 9.1440 & 0.077173 & 100.96 & 25.516 \\
2.2022 & $6.4812 \cdot 10^{-3}$ & 9.5437 & 0.085588 & 111.06 & 30.149 \\
2.3047 & $6.6250 \cdot 10^{-3}$ & 9.9565 & 0.098562 & 121.13 & 35.135 \\
2.4188 & $7.1662 \cdot 10^{-3}$ & 10.377 & 0.10224 & 131.18 & 39.853 \\
2.5244 & $8.0127 \cdot 10^{-3}$ & 10.776 & 0.11061 & 141.30 & 44.617 \\
2.6216 & $8.3186 \cdot 10^{-3}$ & 11.241 & 0.12061 & 151.34 & 49.585 \\
2.7601 & $9.3342 \cdot 10^{-3}$ & 11.734 & 0.13114 & 161.46 & 53.987 \\
2.8758 & $9.5170 \cdot 10^{-3}$ & 12.253 & 0.14861 & 171.51 & 58.558 \\
2.9922 & 0.010245 & 12.800 & 0.16832 & 181.59 & 63.141 \\
3.1283 & 0.011346 & 13.366 & 0.18773 & 191.65 & 67.730 \\
3.2607 & 0.011964 & 13.948 & 0.21073 & 201.78 & 71.822 \\
3.4043 & 0.013133 & 14.584 & 0.23723 & 211.85 & 75.658 \\
3.5526 & 0.013428 & 15.221 & 0.26536 & 221.86 & 79.576 \\
3.7058 & 0.014656 & 15.711 & 0.28618 & 231.93 & 83.133 \\
3.8682 & 0.017036 & 17.202 & 0.36702 & 241.99 & 86.369 \\
4.0414 & 0.017343 & 18.761 & 0.46163 & 252.13 & 89.896 \\
4.2165 & 0.018013 & 20.485 & 0.57965 & 262.20 & 92.824 \\
4.4056 & 0.019009 & 22.447 & 0.72027 & 272.26 & 95.696 \\
4.5993 & 0.021622 & 24.489 & 0.92895 & 282.24 & 98.891 \\
4.8020 & 0.021852 & 26.742 & 1.1648 & 292.42 & 103.22 \\
5.0181 & 0.023796 & 29.228 & 1.4556 & 302.54 & 105.88 \\
5.2339 & 0.026634 & 31.915 & 1.8628 & & \\
5.4675 & 0.028855 & 34.869 & 2.3550 & & \\
5.7094 & 0.029819 & 38.093 & 2.9510 & & \\
5.9567 & 0.034190 & 41.618 & 3.6775 & & \\
6.2168 & 0.035287 & 45.472 & 4.6289 & & \\
6.4818 & 0.039861 & 49.684 & 5.5686 & & \\
6.7740 & 0.039214 & 54.283 & 6.8797 & & \\
7.0709 & 0.044220 & 59.300 & 8.4126 & & \\
7.3830 & 0.053752 & 64.800 & 10.241 & & \\
7.7042 & 0.055988 & 70.801 & 12.429 & &
\end{tabular}


Table 5. Measured molar heat capacity values at constant pressure for $\gamma$-alumina $\mathrm{Al}_{2} \mathrm{O}_{3} \cdot 0.537 \mathrm{H}_{2} \mathrm{O} \cdot M=111.64 \mathrm{~g} \cdot \mathrm{mole}^{-1}$. Measurements were performed using a Quantum Design Physical Properties Measurement System (PPMS) with a standard uncertainty of $2 \% C_{p, \mathrm{~m}}$ below about $T=10 \mathrm{~K}$ and $1 \% C_{p, \mathrm{~m}}$ from $T=(10$ to 300$) \mathrm{K}$. The standard uncertainty in temperature is about $4 \mathrm{mK}$.

\begin{tabular}{|c|c|c|c|c|c|}
\hline$T / \mathrm{K}$ & $C_{p, \mathrm{~m}} / \mathrm{J} \cdot \mathrm{K}^{-1} \cdot \mathrm{mol}^{-1}$ & $T / \mathrm{K}$ & $C_{p, \mathrm{~m}} / \mathrm{J} \cdot \mathrm{K}^{-1} \cdot \mathrm{mol}^{-1}$ & $T / \mathrm{K}$ & $C_{p, \mathrm{~m}} / \mathrm{J} \cdot \mathrm{K}^{-1} \cdot \mathrm{mol}^{-1}$ \\
\hline 1.8303 & $2.4664 \cdot 10^{-3}$ & 8.0372 & 0.034744 & 77.380 & 12.678 \\
\hline 1.9136 & $2.6083 \cdot 10^{-3}$ & 8.3941 & 0.038167 & 84.554 & 15.520 \\
\hline 1.9972 & $2.7364 \cdot 10^{-3}$ & 8.7599 & 0.039742 & 92.394 & 18.711 \\
\hline 2.0865 & $3.0145 \cdot 10^{-3}$ & 9.1417 & 0.045237 & 100.96 & 22.183 \\
\hline 2.1796 & $3.1722 \cdot 10^{-3}$ & 9.5397 & 0.050929 & 111.07 & 26.476 \\
\hline 2.2774 & $3.3957 \cdot 10^{-3}$ & 9.9577 & 0.052647 & 121.13 & 31.004 \\
\hline 2.3812 & $3.5842 \cdot 10^{-3}$ & 10.374 & 0.059973 & 131.18 & 35.413 \\
\hline 2.5320 & $4.0125 \cdot 10^{-3}$ & 10.776 & 0.066026 & 141.30 & 39.850 \\
\hline 2.6304 & $4.1703 \cdot 10^{-3}$ & 11.242 & 0.072119 & 151.38 & 44.512 \\
\hline 2.7668 & $4.3975 \cdot 10^{-3}$ & 11.735 & 0.079604 & 161.47 & 48.611 \\
\hline 2.8602 & $4.8795 \cdot 10^{-3}$ & 12.256 & 0.090685 & 171.51 & 52.980 \\
\hline 2.9964 & $5.1834 \cdot 10^{-3}$ & 12.802 & 0.10315 & 181.58 & 57.310 \\
\hline 3.1319 & $5.7698 \cdot 10^{-3}$ & 13.364 & 0.11846 & 191.65 & 61.289 \\
\hline 3.2563 & $5.9625 \cdot 10^{-3}$ & 13.961 & 0.13382 & 201.78 & 65.178 \\
\hline 3.4162 & $6.4169 \cdot 10^{-3}$ & 14.578 & 0.15047 & 211.85 & 68.887 \\
\hline 3.5487 & $6.7830 \cdot 10^{-3}$ & 15.209 & 0.16964 & 221.86 & 72.500 \\
\hline 3.7087 & $7.0645 \cdot 10^{-3}$ & 15.730 & 0.18518 & 231.93 & 75.819 \\
\hline 3.8715 & $7.7740 \cdot 10^{-3}$ & 17.168 & 0.23876 & 241.99 & 78.815 \\
\hline 4.0389 & $8.2889 \cdot 10^{-3}$ & 18.796 & 0.30686 & 252.14 & 82.214 \\
\hline 4.2177 & 0.010271 & 20.542 & 0.39464 & 262.20 & 84.989 \\
\hline 4.4039 & $9.0607 \cdot 10^{-3}$ & 22.428 & 0.50199 & 272.26 & 87.762 \\
\hline 4.5945 & $9.6190 \cdot 10^{-3}$ & 24.501 & 0.60224 & 282.24 & 90.715 \\
\hline 4.7975 & 0.012090 & 26.745 & 0.81760 & 292.38 & 93.165 \\
\hline 5.0117 & 0.012749 & 29.213 & 1.0531 & 302.47 & 95.935 \\
\hline 5.2333 & 0.014574 & 31.923 & 1.3438 & & \\
\hline 5.4646 & 0.015047 & 34.876 & 1.7264 & & \\
\hline 5.7036 & 0.016184 & 38.098 & 2.1962 & & \\
\hline 5.9554 & 0.017458 & 41.623 & 2.7840 & & \\
\hline 6.2186 & 0.016214 & 45.477 & 3.5478 & & \\
\hline 6.4761 & 0.019408 & 49.693 & 4.3585 & & \\
\hline 6.7701 & 0.020881 & 54.292 & 5.4730 & & \\
\hline 7.0670 & 0.025530 & 59.313 & 6.8176 & & \\
\hline 7.3761 & 0.027830 & 64.806 & 8.4043 & & \\
\hline 7.6972 & 0.029963 & 70.812 & 10.343 & & \\
\hline
\end{tabular}


Table 6. Measured molar heat capacity values at constant pressure for $\gamma$-alumina $\mathrm{Al}_{2} \mathrm{O}_{3} \cdot 0.204 \mathrm{H}_{2} \mathrm{O} . M=105.64 \mathrm{~g} \cdot \mathrm{mole}^{-1}$. Measurements were performed using a Quantum Design Physical Properties Measurement System (PPMS) with a standard uncertainty of $2 \% \mathrm{C}_{p, \mathrm{~m}}$ below about $T=10 \mathrm{~K}$ and $1 \% \mathrm{C}_{p, \mathrm{~m}}$ from $T=(10$ to 300$) \mathrm{K}$. The standard uncertainty in temperature is about $4 \mathrm{mK}$.

\begin{tabular}{|c|c|c|c|c|c|}
\hline$T / \mathrm{K}$ & $C_{\mathrm{p}, \mathrm{m}} / \mathrm{J} \cdot \mathrm{K}^{-1} \cdot \mathrm{mol}^{-1}$ & $T / \mathrm{K}$ & $C_{\mathrm{p}, \mathrm{m}} / \mathrm{J} \cdot \mathrm{K}^{-1} \cdot \mathrm{mol}^{-1}$ & $T / \mathrm{K}$ & $C_{\mathrm{p}, \mathrm{m}} / \mathrm{J} \cdot \mathrm{K}^{-1} \cdot \mathrm{mol}^{-1}$ \\
\hline 1.8408 & $1.8613 \cdot 10^{-3}$ & 8.0328 & 0.018257 & 77.369 & 10.525 \\
\hline 1.9156 & $1.9710 \cdot 10^{-3}$ & 8.3877 & 0.019846 & 84.549 & 13.048 \\
\hline 2.0048 & $2.0219 \cdot 10^{-3}$ & 8.7470 & 0.023498 & 92.391 & 15.918 \\
\hline 2.0995 & $2.0712 \cdot 10^{-3}$ & 9.1293 & 0.028371 & 100.96 & 19.076 \\
\hline 2.1998 & $2.2269 \cdot 10^{-3}$ & 9.5258 & 0.030510 & 111.07 & 23.000 \\
\hline 2.3049 & $2.3718 \cdot 10^{-3}$ & 9.9471 & 0.031589 & 121.13 & 27.121 \\
\hline 2.4159 & $2.3029 \cdot 10^{-3}$ & 10.366 & 0.035262 & 131.18 & 31.129 \\
\hline 2.5286 & $2.5059 \cdot 10^{-3}$ & 10.771 & 0.038710 & 141.30 & 35.159 \\
\hline 2.6416 & $2.7797 \cdot 10^{-3}$ & 11.237 & 0.042484 & 151.34 & 39.301 \\
\hline 2.7543 & $2.7910 \cdot 10^{-3}$ & 11.731 & 0.046645 & 161.46 & 43.177 \\
\hline 2.8609 & $3.0467 \cdot 10^{-3}$ & 12.250 & 0.054083 & 171.50 & 47.060 \\
\hline 2.9893 & $3.1918 \cdot 10^{-3}$ & 12.794 & 0.062205 & 181.58 & 50.964 \\
\hline 3.1165 & $3.3522 \cdot 10^{-3}$ & 13.360 & 0.070863 & 191.64 & 54.694 \\
\hline 3.2613 & $3.6422 \cdot 10^{-3}$ & 13.943 & 0.080488 & 201.76 & 58.236 \\
\hline 3.4114 & $3.2396 \cdot 10^{-3}$ & 14.575 & 0.091860 & 211.83 & 61.592 \\
\hline 3.5467 & $3.4625 \cdot 10^{-3}$ & 15.215 & 0.10368 & 221.85 & 64.676 \\
\hline 3.7046 & $4.0716 \cdot 10^{-3}$ & 15.710 & 0.11277 & 231.90 & 67.712 \\
\hline 3.8611 & $3.8493 \cdot 10^{-3}$ & 17.186 & 0.14742 & 241.96 & 70.511 \\
\hline 4.0328 & $4.7409 \cdot 10^{-3}$ & 18.763 & 0.19058 & 252.11 & 73.499 \\
\hline 4.2136 & $5.4852 \cdot 10^{-3}$ & 20.481 & 0.24514 & 262.17 & 76.088 \\
\hline 4.4016 & $5.1204 \cdot 10^{-3}$ & 22.432 & 0.31815 & 272.23 & 78.564 \\
\hline 4.5905 & $5.6301 \cdot 10^{-3}$ & 24.477 & 0.40854 & 282.21 & 81.119 \\
\hline 4.7941 & $5.9969 \cdot 10^{-3}$ & 26.739 & 0.53532 & 292.34 & 83.284 \\
\hline 5.0049 & $6.9060 \cdot 10^{-3}$ & 29.230 & 0.71504 & 302.42 & 85.702 \\
\hline 5.2272 & $7.9715 \cdot 10^{-3}$ & 31.910 & 0.90945 & & \\
\hline 5.4592 & $7.6227 \cdot 10^{-3}$ & 34.868 & 1.1882 & & \\
\hline 5.6962 & $8.9379 \cdot 10^{-3}$ & 38.091 & 1.5459 & & \\
\hline 5.9487 & $8.4764 \cdot 10^{-3}$ & 41.616 & 2.0014 & & \\
\hline 6.2064 & 0.010989 & 45.468 & 2.6095 & & \\
\hline 6.4737 & 0.010983 & 49.683 & 3.2799 & & \\
\hline 6.7586 & 0.014165 & 54.283 & 4.2210 & & \\
\hline 7.0600 & 0.014696 & 59.302 & 5.3464 & & \\
\hline 7.3709 & 0.016581 & 64.800 & 6.7364 & & \\
\hline 7.6919 & 0.018607 & 70.803 & 8.4567 & & \\
\hline
\end{tabular}


Table 7. Parameters for low $T(<15 \mathrm{~K})$, mid $T(10 \mathrm{~K}<T<60 \mathrm{~K})$, and high $T(>50 \mathrm{~K})$ fits of heat capacity data (in $\mathrm{J} \cdot \mathrm{K}^{-1} \cdot \mathrm{mol}^{-1}$ ) for all $\gamma$-alumina samples.

\begin{tabular}{|c|c|c|c|c|c|}
\hline & Parameter & $\mathrm{Al}_{2} \mathrm{O}_{3} \cdot 1.540 \mathrm{H}_{2} \mathrm{O}$ & $\mathrm{Al}_{2} \mathrm{O}_{3} \cdot 0.811 \mathrm{H}_{2} \mathrm{O}$ & $\mathrm{Al}_{2} \mathrm{O}_{3} \cdot 0.537 \mathrm{H}_{2} \mathrm{O}$ & $\mathrm{Al}_{2} \mathrm{O}_{3} \cdot 0.204 \mathrm{H}_{2} \mathrm{O}$ \\
\hline \multirow{8}{*}{$\begin{array}{l}\text { 坣 } \\
\text { H } \\
z \\
0 \\
0\end{array}$} & $\gamma / \mathrm{J} \cdot \mathrm{K}^{-2} \cdot \mathrm{mol}^{-1}$ & $1.8106 \cdot 10^{-3}$ & $2.3019 \cdot 10^{-3}$ & $1.2049 \cdot 10^{-3}$ & $9.4499 \cdot 10^{-4}$ \\
\hline & $B_{3} / \mathrm{J} \cdot \mathrm{K}^{-4} \cdot \mathrm{mol}^{-1}$ & $1.9107 \cdot 10^{-4}$ & $1.2846 \cdot 10^{-4}$ & $5.6263 \cdot 10^{-5}$ & $7.1098 \cdot 10^{-6}$ \\
\hline & $B_{5} / \mathrm{J} \cdot \mathrm{K}^{-6} \cdot \mathrm{mol}^{-1}$ & $-1.5893 \cdot 10^{-6}$ & $-1.1686 \cdot 10^{-6}$ & $-2.7605 \cdot 10^{-7}$ & $4.0012 \cdot 10^{-7}$ \\
\hline & $B_{7} / \mathrm{J} \cdot \mathrm{K}^{-8} \cdot \mathrm{mol}^{-1}$ & $9.7195 \cdot 10^{-9}$ & $7.2062 \cdot 10^{-9}$ & $1.6819 \cdot 10^{-9}$ & $-3.0420 \cdot 10^{-9}$ \\
\hline & $B_{9} / \mathrm{J} \cdot \mathrm{K}^{-10} \cdot \mathrm{mol}^{-1}$ & $-1.9932 \cdot 10^{-11}$ & $-1.4524 \cdot 10^{-11}$ & $-3.1904 \cdot 10^{-12}$ & $7.2731 \cdot 10^{-12}$ \\
\hline & $n / \mathrm{mol}$ & $1.1272 \cdot 10^{-4}$ & $1.1289 \cdot 10^{-4}$ & $1.6572 \cdot 10^{-4}$ & $2.0618 \cdot 10^{-4}$ \\
\hline & $\%$ RMS & 3.99 & 3.93 & 4.52 & 5.75 \\
\hline & Range / K & $1.829-11.89$ & $1.825-11.31$ & $1.830-10.67$ & $1.841-12.23$ \\
\hline \multirow{9}{*}{ 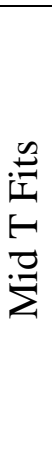 } & $A_{0} / \mathrm{J} \cdot \mathrm{K}^{-1} \cdot \mathrm{mol}^{-1}$ & $6.9436 \cdot 10^{-1}$ & $8.6311 \cdot 10^{-1}$ & $1.6377 \cdot 10^{-1}$ & $2.1960 \cdot 10^{-1}$ \\
\hline & $A_{l} / \mathrm{J} \cdot \mathrm{K}^{-2} \cdot \mathrm{mol}^{-1}$ & $-1.9577 \cdot 10^{-1}$ & $-2.3918 \cdot 10^{-1}$ & $-4.1986 \cdot 10^{-2}$ & $-5.9080 \cdot 10^{-2}$ \\
\hline & $A_{2} / \mathrm{J} \cdot \mathrm{K}^{-3} \cdot \mathrm{mol}^{-1}$ & $2.1672 \cdot 10^{-2}$ & $2.6290 \cdot 10^{-2}$ & $4.2491 \cdot 10^{-3}$ & $6.1862 \cdot 10^{-3}$ \\
\hline & $A_{3} / \mathrm{J} \cdot \mathrm{K}^{-4} \cdot \mathrm{mol}^{-1}$ & $-1.0271 \cdot 10^{-3}$ & $-1.3459 \cdot 10^{-3}$ & $-1.5631 \cdot 10^{-4}$ & $-2.8763 \cdot 10^{-4}$ \\
\hline & $A_{4} / \mathrm{J} \cdot \mathrm{K}^{-5} \cdot \mathrm{mol}^{-1}$ & $2.91564 \cdot 10^{-5}$ & $3.9491 \cdot 10^{-5}$ & $4.7829 \cdot 10^{-6}$ & $8.2701 \cdot 10^{-6}$ \\
\hline & $A_{5} / \mathrm{J} \cdot \mathrm{K}^{-6} \cdot \mathrm{mol}^{-1}$ & $-4.03541 \cdot 10^{-7}$ & $-5.6321 \cdot 10^{-7}$ & $-5.9841 \cdot 10^{-8}$ & $-1.0523 \cdot 10^{-7}$ \\
\hline & $A_{6} / \mathrm{J} \cdot \mathrm{K}^{-7} \cdot \mathrm{mol}^{-1}$ & $2.15701 \cdot 10^{-9}$ & $3.1023 \cdot 10^{-9}$ & $2.6623 \cdot 10^{-10}$ & $4.9964 \cdot 10^{-10}$ \\
\hline & $\%$ RMS & 0.684 & 0.726 & 1.44 & 0.986 \\
\hline & Range / K & $11.89-58.63$ & $11.31-55.68$ & $10.67-53.40$ & $12.23-50.27$ \\
\hline \multirow{7}{*}{ 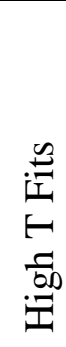 } & $\mathrm{m} / \mathrm{mol}$ & 3.5546 & 3.1102 & 2.6902 & 2.6004 \\
\hline & $\Theta_{D} / \mathrm{K}$ & 617.25 & 612.74 & 585.54 & 597.49 \\
\hline & $n / \mathrm{mol}$ & 3.3452 & 2.5099 & 2.6552 & 2.4546 \\
\hline & $\Theta_{E} / \mathrm{K}$ & 978.8 & 1024.0 & 928.86 & 939.12 \\
\hline & $A_{1}$ & $5.8894 \cdot 10^{-2}$ & $5.1127 \cdot 10^{-2}$ & $2.5617 \cdot 10^{-2}$ & $8.9594 \cdot 10^{-3}$ \\
\hline & $\% \mathrm{RM}$ & 0.476 & 0.985 & 0.438 & 0.355 \\
\hline & Range / K & $58.63-302.52$ & $55.68-302.54$ & $53.40-302.47$ & $50.27-302.42$ \\
\hline
\end{tabular}


TABLE 8. Standard thermodynamic functions of $\gamma$-alumina $\mathrm{Al}_{2} \mathrm{O}_{3} \cdot 1.540 \mathrm{H}_{2} \mathrm{O} . \Phi_{\mathrm{m}}{ }^{\circ=} \Delta^{\mathrm{T}} S_{\mathrm{m}}{ }^{\mathrm{o}}-$ $\Delta^{\mathrm{T}} H_{\mathrm{m}} \mathrm{q} T . M=129.70 \mathrm{~g} \cdot \mathrm{mole}^{-1}$. All calculated thermodynamic values have an estimated standard uncertainty of about $0.02 \mathrm{X}$ below $10 \mathrm{~K}$ and $0.01 \mathrm{X}$ above $10 \mathrm{~K}$ where $\mathrm{X}$ represents the thermodynamic property.

\begin{tabular}{|c|c|c|c|c|}
\hline$T / \mathrm{K}$ & $C_{p, \mathrm{~m}} / \mathrm{J} \cdot \mathrm{K}^{-1} \cdot \mathrm{mol}^{-1}$ & $\Delta^{\mathrm{T}} S_{\mathrm{m}}^{\circ} / \mathrm{J} \cdot \mathrm{K}^{-1} \cdot \mathrm{mol}^{-1}$ & $\Delta_{\mathrm{o}}^{\mathrm{T}} H_{\mathrm{m}}^{\circ} / \mathrm{kJ} \cdot \mathrm{mol}^{-1}$ & $\varphi_{\mathrm{m}}^{\circ} / \mathrm{J} \cdot \mathrm{K}^{-1} \cdot \mathrm{mol}^{-1}$ \\
\hline 0 & 0 & 0 & 0 & 0 \\
\hline 1 & $2.000 \cdot 10^{-3}$ & $1.874 \cdot 10^{-3}$ & $9.528 \cdot 10^{-7}$ & $9.212 \cdot 10^{-4}$ \\
\hline 2 & $5.100 \cdot 10^{-3}$ & $4.121 \cdot 10^{-3}$ & $4.369 \cdot 10^{-6}$ & $1.936 \cdot 10^{-3}$ \\
\hline 3 & 0.01023 & $7.077 \cdot 10^{-3}$ & $1.183 \cdot 10^{-5}$ & $3.133 \cdot 10^{-3}$ \\
\hline 4 & 0.01800 & 0.01102 & $2.571 \cdot 10^{-5}$ & $4.589 \cdot 10^{-3}$ \\
\hline 5 & 0.02869 & 0.01612 & $4.880 \cdot 10^{-5}$ & $6.364 \cdot 10^{-3}$ \\
\hline 6 & 0.04230 & 0.02252 & $8.406 \cdot 10^{-5}$ & $8.505 \cdot 10^{-3}$ \\
\hline 7 & 0.05870 & 0.03023 & $1.343 \cdot 10^{-4}$ & 0.01104 \\
\hline 8 & 0.07794 & 0.03929 & $2.024 \cdot 10^{-4}$ & 0.01399 \\
\hline 9 & 0.10050 & 0.04974 & $2.913 \cdot 10^{-4}$ & 0.01737 \\
\hline 10 & 0.12750 & 0.06168 & $4.049 \cdot 10^{-4}$ & 0.02119 \\
\hline 15 & 0.36159 & 0.15214 & $1.560 \cdot 10^{-3}$ & 0.04817 \\
\hline 20 & 0.74231 & 0.30501 & $4.262 \cdot 10^{-3}$ & 0.09191 \\
\hline 25 & 1.2708 & 0.52443 & $9.228 \cdot 10^{-3}$ & 0.15533 \\
\hline 30 & 1.9758 & 0.81557 & 0.01727 & 0.24007 \\
\hline 35 & 2.8742 & 1.1851 & 0.02931 & 0.34771 \\
\hline 40 & 3.9530 & 1.6375 & 0.04631 & 0.47979 \\
\hline 45 & 5.1760 & 2.1725 & 0.06908 & 0.63740 \\
\hline 50 & 6.5139 & 2.7861 & 0.09826 & 0.82096 \\
\hline 60 & 9.7393 & 4.2445 & 0.17874 & 1.2655 \\
\hline 70 & 13.642 & 6.0297 & 0.29505 & 1.8147 \\
\hline 80 & 18.187 & 8.1417 & 0.45372 & 2.4702 \\
\hline 90 & 23.215 & 10.570 & 0.66039 & 3.2325 \\
\hline 100 & 28.579 & 13.291 & 0.91914 & 4.1000 \\
\hline 110 & 34.157 & 16.275 & 1.2327 & 5.0693 \\
\hline 120 & 39.861 & 19.491 & 1.6027 & 6.1357 \\
\hline 130 & 45.626 & 22.909 & 2.0301 & 7.2933 \\
\hline 140 & 51.404 & 26.502 & 2.5153 & 8.5361 \\
\hline 150 & 57.154 & 30.245 & 3.0581 & 9.8578 \\
\hline 160 & 62.843 & 34.116 & 3.6581 & 11.252 \\
\hline 170 & 68.441 & 38.094 & 4.3146 & 12.714 \\
\hline 180 & 73.924 & 42.162 & 5.0266 & 14.236 \\
\hline 190 & 79.272 & 46.303 & 5.7927 & 15.815 \\
\hline 200 & 84.467 & 50.502 & 6.6115 & 17.444 \\
\hline 210 & 89.499 & 54.745 & 7.4815 & 19.119 \\
\hline 220 & 94.357 & 59.021 & 8.4009 & 20.836 \\
\hline 230 & 99.036 & 63.320 & 9.3680 & 22.589 \\
\hline
\end{tabular}




$\begin{array}{lllll}240 & 103.53 & 67.630 & 10.381 & 24.376 \\ 250 & 107.85 & 71.945 & 11.438 & 26.192 \\ 260 & 111.99 & 76.256 & 12.537 & 28.035 \\ 270 & 115.95 & 80.557 & 13.677 & 29.901 \\ 273.15 & 117.16 & 81.909 & 14.044 & 30.493 \\ 280 & 119.74 & 84.843 & 14.856 & 31.787 \\ 290 & 123.37 & 89.109 & 16.072 & 33.690 \\ 298.15 & 126.21 & 92.568 & 17.089 & 35.252 \\ 300 & 126.84 & 93.350 & 17.323 & 35.608\end{array}$


Table 9. Standard thermodynamic functions of $\gamma$-alumina $\mathrm{Al}_{2} \mathrm{O}_{3} \cdot 0.811 \mathrm{H}_{2} \mathrm{O} \cdot \Phi_{\mathrm{m}}{ }^{\circ}=\Delta^{\mathrm{T}} S_{\mathrm{m}}{ }^{\mathrm{o}}-$ $\Delta^{\mathrm{T}} H_{\mathrm{m}} \mathrm{g} / \mathrm{T} . M=116.57 \mathrm{~g} \cdot \mathrm{mole}^{-1}$. All calculated thermodynamic values have an estimated standard uncertainty of about $0.02 \mathrm{X}$ below $10 \mathrm{~K}$ and $0.01 \mathrm{X}$ above $10 \mathrm{~K}$ where $\mathrm{X}$ represents the thermodynamic property.

\begin{tabular}{|c|c|c|c|c|}
\hline$T / \mathrm{K}$ & $C_{p, \mathrm{~m}} / \mathrm{J} \cdot \mathrm{K}^{-1} \cdot \mathrm{mol}^{-1}$ & $\Delta^{\mathrm{T}} S_{\mathrm{m}}^{\circ} / \mathrm{J} \cdot \mathrm{K}^{-1} \cdot \mathrm{mol}^{-1}$ & $\Delta^{\mathrm{T}} H_{\mathrm{m}}^{\circ} / \mathrm{kJ}^{\prime} \cdot \mathrm{mol}^{-1}$ & $\varphi_{\mathrm{m}}^{\circ} / \mathrm{J} \cdot \mathrm{K}^{-1} \cdot \mathrm{mol}^{-1}$ \\
\hline 0 & 0 & 0 & 0 & 0 \\
\hline 1 & $2.429 \cdot 10^{-3}$ & $2.345 \cdot 10^{-3}$ & $1.183 \cdot 10^{-6}$ & $1.162 \cdot 10^{-3}$ \\
\hline 2 & $5.595 \cdot 10^{-3}$ & $4.939 \cdot 10^{-3}$ & $5.105 \cdot 10^{-6}$ & $2.386 \cdot 10^{-3}$ \\
\hline 3 & 0.01011 & $8.007 \cdot 10^{-3}$ & $1.282 \cdot 10^{-5}$ & $3.733 \cdot 10^{-3}$ \\
\hline 4 & 0.01635 & 0.01173 & $2.590 \cdot 10^{-5}$ & $5.251 \cdot 10^{-3}$ \\
\hline 5 & 0.02445 & 0.01621 & $4.614 \cdot 10^{-5}$ & $6.981 \cdot 10^{-3}$ \\
\hline 6 & 0.03434 & 0.02152 & $7.539 \cdot 10^{-5}$ & $8.950 \cdot 10^{-3}$ \\
\hline 7 & 0.04588 & 0.02766 & $1.154 \cdot 10^{-4}$ & 0.01117 \\
\hline 8 & 0.05906 & 0.03462 & $1.677 \cdot 10^{-4}$ & 0.01366 \\
\hline 9 & 0.07420 & 0.04243 & $2.341 \cdot 10^{-4}$ & 0.01642 \\
\hline 10 & 0.09216 & 0.05115 & $3.170 \cdot 10^{-4}$ & 0.01944 \\
\hline 15 & 0.25520 & 0.11483 & $1.129 \cdot 10^{-3}$ & 0.03953 \\
\hline 20 & 0.54324 & 0.22482 & $3.075 \cdot 10^{-3}$ & 0.07105 \\
\hline 25 & 0.96877 & 0.38881 & $6.789 \cdot 10^{-3}$ & 0.11724 \\
\hline 30 & 1.5728 & 0.61587 & 0.01306 & 0.18047 \\
\hline 35 & 2.3750 & 0.91607 & 0.02285 & 0.26319 \\
\hline 40 & 3.3539 & 1.2954 & 0.03711 & 0.36768 \\
\hline 45 & 4.4630 & 1.7534 & 0.05660 & 0.49549 \\
\hline 50 & 5.6812 & 2.2856 & 0.08191 & 0.64729 \\
\hline 60 & 8.6107 & 3.5735 & 0.15300 & 1.0234 \\
\hline 70 & 12.066 & 5.1523 & 0.25587 & 1.4971 \\
\hline 80 & 16.070 & 7.0197 & 0.39616 & 2.0677 \\
\hline 90 & 20.464 & 9.1631 & 0.57857 & 2.7345 \\
\hline 100 & 25.100 & 11.558 & 0.80624 & 3.4952 \\
\hline 110 & 29.861 & 14.172 & 1.0810 & 4.3454 \\
\hline 120 & 34.667 & 16.977 & 1.4036 & 5.2800 \\
\hline 130 & 39.462 & 19.941 & 1.7743 & 6.2928 \\
\hline 140 & 44.211 & 23.040 & 2.1927 & 7.3776 \\
\hline 150 & 48.891 & 26.250 & 2.6583 & 8.5282 \\
\hline 160 & 53.483 & 29.552 & 3.1702 & 9.7386 \\
\hline 170 & 57.975 & 32.930 & 3.7276 & 11.003 \\
\hline 180 & 62.355 & 36.368 & 4.3293 & 12.317 \\
\hline 190 & 66.614 & 39.854 & 4.9743 & 13.674 \\
\hline 200 & 70.745 & 43.377 & 5.6612 & 15.071 \\
\hline 210 & 74.742 & 46.926 & 6.3888 & 16.503 \\
\hline 220 & 78.601 & 50.492 & 7.1556 & 17.967 \\
\hline 230 & 82.321 & 54.069 & 7.9603 & 19.459 \\
\hline
\end{tabular}




$\begin{array}{lllll}240 & 85.901 & 57.649 & 8.8015 & 20.976 \\ 250 & 89.341 & 61.226 & 9.6779 & 22.514 \\ 260 & 92.644 & 64.794 & 10.588 & 24.072 \\ 270 & 95.813 & 68.351 & 11.530 & 25.646 \\ 273.15 & 96.784 & 69.468 & 11.834 & 26.145 \\ 280 & 98.851 & 71.890 & 12.504 & 27.234 \\ 290 & 101.76 & 75.410 & 13.507 & 28.835 \\ 298.15 & 104.05 & 78.262 & 14.346 & 30.147 \\ 300 & 104.55 & 78.908 & 14.539 & 30.446\end{array}$


Table 10. Standard thermodynamic functions of $\gamma$-alumina $\mathrm{Al}_{2} \mathrm{O}_{3} \cdot 0.537 \mathrm{H}_{2} \mathrm{O} . \Phi_{\mathrm{m}}{ }^{\circ=} \Delta^{\mathrm{T}} S_{\mathrm{m}}{ }^{\mathrm{o}}$ $\Delta^{\mathrm{T}} H_{\mathrm{m}} \mathrm{q} / T . M=111.64 \mathrm{~g} \cdot \mathrm{mole}^{-1}$. All calculated thermodynamic values have an estimated standard uncertainty of about $0.02 \mathrm{X}$ below $10 \mathrm{~K}$ and $0.01 \mathrm{X}$ above $10 \mathrm{~K}$ where $\mathrm{X}$ represents the thermodynamic property.

\begin{tabular}{|c|c|c|c|c|}
\hline$T / \mathrm{K}$ & $C_{p, \mathrm{~m}} / \mathrm{J} \cdot \mathrm{K}^{-1} \cdot \mathrm{mol}^{-1}$ & $\Delta_{\mathrm{o}}^{\mathrm{T}} S_{\mathrm{m}}^{\circ} / \mathrm{J} \cdot \mathrm{K}^{-1} \cdot \mathrm{mol}^{-1}$ & $\Delta_{0}^{\mathrm{T}} H_{\mathrm{m}}^{\circ} / \mathrm{kJ}^{\prime} \mathrm{mol}^{-1}$ & $\varphi_{\mathrm{m}}^{\circ} / \mathrm{J} \cdot \mathrm{K}^{-1} \cdot \mathrm{mol}^{-1}$ \\
\hline 0 & 0 & 0 & 0 & 0 \\
\hline 1 & $1.261 \cdot 10^{-3}$ & $1.224 \cdot 10^{-3}$ & $6.165 \cdot 10^{-7}$ & $6.072 \cdot 10^{-4}$ \\
\hline 2 & $2.851 \cdot 10^{-3}$ & $2.558 \cdot 10^{-3}$ & $2.632 \cdot 10^{-6}$ & $1.242 \cdot 10^{-3}$ \\
\hline 3 & $5.070 \cdot 10^{-3}$ & $4.108 \cdot 10^{-3}$ & $6.529 \cdot 10^{-6}$ & $1.932 \cdot 10^{-3}$ \\
\hline 4 & $8.165 \cdot 10^{-3}$ & $5.967 \cdot 10^{-3}$ & $1.307 \cdot 10^{-5}$ & $2.701 \cdot 10^{-3}$ \\
\hline 5 & 0.01232 & $8.215 \cdot 10^{-3}$ & $2.321 \cdot 10^{-5}$ & $3.572 \cdot 10^{-3}$ \\
\hline 6 & 0.01767 & 0.01091 & $3.811 \cdot 10^{-5}$ & $4.564 \cdot 10^{-3}$ \\
\hline 7 & 0.02435 & 0.01412 & $5.900 \cdot 10^{-5}$ & $5.694 \cdot 10^{-3}$ \\
\hline 8 & 0.03250 & 0.01789 & $8.730 \cdot 10^{-5}$ & $6.977 \cdot 10^{-3}$ \\
\hline 9 & 0.04237 & 0.02227 & $1.246 \cdot 10^{-4}$ & $8.427 \cdot 10^{-3}$ \\
\hline 10 & 0.05434 & 0.02733 & $1.727 \cdot 10^{-4}$ & 0.01006 \\
\hline 15 & 0.16308 & 0.06668 & $6.761 \cdot 10^{-4}$ & 0.02161 \\
\hline 20 & 0.36309 & 0.13881 & $1.954 \cdot 10^{-3}$ & 0.04114 \\
\hline 25 & 0.66947 & 0.25045 & $4.483 \cdot 10^{-3}$ & 0.07112 \\
\hline 30 & 1.1176 & 0.40973 & $8.885 \cdot 10^{-3}$ & 0.11355 \\
\hline 35 & 1.7315 & 0.62592 & 0.01594 & 0.17058 \\
\hline 40 & 2.5121 & 0.90631 & 0.02648 & 0.24433 \\
\hline 45 & 3.4415 & 1.2545 & 0.04131 & 0.33659 \\
\hline 50 & 4.4964 & 1.6707 & 0.06110 & 0.44863 \\
\hline 60 & 6.9887 & 2.7017 & 0.11803 & 0.73455 \\
\hline 70 & 10.082 & 4.0042 & 0.20292 & 1.1053 \\
\hline 80 & 13.669 & 5.5799 & 0.32132 & 1.5634 \\
\hline 90 & 17.610 & 7.4146 & 0.47748 & 2.1093 \\
\hline 100 & 21.786 & 9.4845 & 0.67431 & 2.7415 \\
\hline 110 & 26.109 & 11.763 & 0.91369 & 3.4565 \\
\hline 120 & 30.513 & 14.223 & 1.1968 & 4.2501 \\
\hline 130 & 34.952 & 16.841 & 1.5241 & 5.1170 \\
\hline 140 & 39.388 & 19.593 & 1.8958 & 6.0519 \\
\hline 150 & 43.788 & 22.461 & 2.3117 & 7.0497 \\
\hline 160 & 48.124 & 25.426 & 2.7713 & 8.1051 \\
\hline 170 & 52.372 & 28.471 & 3.2739 & 9.2132 \\
\hline 180 & 56.513 & 31.583 & 3.8184 & 10.369 \\
\hline 190 & 60.530 & 34.746 & 4.4037 & 11.569 \\
\hline 200 & 64.410 & 37.950 & 5.0286 & 12.808 \\
\hline 210 & 68.145 & 41.184 & 5.6915 & 14.082 \\
\hline 220 & 71.729 & 44.437 & 6.3910 & 15.388 \\
\hline 230 & 75.160 & 47.702 & 7.1255 & 16.722 \\
\hline 240 & 78.437 & 50.971 & 7.8936 & 18.081 \\
\hline
\end{tabular}




$\begin{array}{lllll}250 & 81.563 & 54.237 & 8.6938 & 19.461 \\ 260 & 84.539 & 57.494 & 9.5244 & 20.862 \\ 270 & 87.371 & 60.738 & 10.384 & 22.279 \\ 273.15 & 88.234 & 61.756 & 10.661 & 22.728 \\ 280 & 90.064 & 63.965 & 11.271 & 23.710 \\ 290 & 92.624 & 67.170 & 12.185 & 25.153 \\ 298.15 & 94.615 & 69.765 & 12.948 & 26.337 \\ 300 & 95.056 & 70.352 & 13.123 & 26.607\end{array}$


Table 11. Standard thermodynamic functions of $\gamma$-alumina $\mathrm{Al}_{2} \mathrm{O}_{3} \cdot 0.204 \mathrm{H}_{2} \mathrm{O} . \Phi_{\mathrm{m}}{ }^{\circ=} \Delta^{\mathrm{T}} S_{\mathrm{m}}{ }^{\mathrm{o}}$ $\Delta^{\mathrm{T}} H_{\mathrm{m}} \mathrm{q} / T . M=105.64 \mathrm{~g} \cdot \mathrm{mole}^{-1}$ All calculated thermodynamic values have an estimated standard uncertainty of about $0.02 \mathrm{X}$ below $10 \mathrm{~K}$ and $0.01 \mathrm{X}$ above $10 \mathrm{~K}$ where $\mathrm{X}$ represents the thermodynamic property.

\begin{tabular}{|c|c|c|c|c|}
\hline$T / \mathrm{K}$ & $C_{p, \mathrm{~m}} / \mathrm{J} \cdot \mathrm{K}^{-1} \cdot \mathrm{mol}^{-1}$ & $\Delta_{\mathrm{o}}^{\mathrm{T}} S_{\mathrm{m}}^{\circ} / \mathrm{J} \cdot \mathrm{K}^{-1} \cdot \mathrm{mol}^{-1}$ & $\Delta_{0}^{\mathrm{T}} H_{\mathrm{m}}^{\circ} / \mathrm{kJ}^{\prime} \mathrm{mol}^{-1}$ & $\varphi_{\mathrm{m}}^{\circ} / \mathrm{J} \cdot \mathrm{K}^{-1} \cdot \mathrm{mol}^{-1}$ \\
\hline 0 & 0 & 0 & 0 & 0 \\
\hline 1 & $9.525 \cdot 10^{-4}$ & $9.474 \cdot 10^{-4}$ & $4.743 \cdot 10^{-7}$ & $4.731 \cdot 10^{-4}$ \\
\hline 2 & $1.959 \cdot 10^{-3}$ & $1.911 \cdot 10^{-3}$ & $1.923 \cdot 10^{-6}$ & $9.501 \cdot 10^{-4}$ \\
\hline 3 & $3.117 \cdot 10^{-3}$ & $2.917 \cdot 10^{-3}$ & $4.442 \cdot 10^{-6}$ & $1.437 \cdot 10^{-3}$ \\
\hline 4 & $4.596 \cdot 10^{-3}$ & $4.007 \cdot 10^{-3}$ & $8.264 \cdot 10^{-6}$ & $1.941 \cdot 10^{-3}$ \\
\hline 5 & $6.640 \cdot 10^{-3}$ & $5.239 \cdot 10^{-3}$ & $1.382 \cdot 10^{-5}$ & $2.474 \cdot 10^{-3}$ \\
\hline 6 & $9.537 \cdot 10^{-3}$ & $6.690 \cdot 10^{-3}$ & $2.183 \cdot 10^{-5}$ & $3.052 \cdot 10^{-3}$ \\
\hline 7 & 0.01356 & $8.447 \cdot 10^{-3}$ & $3.328 \cdot 10^{-5}$ & $3.693 \cdot 10^{-3}$ \\
\hline 8 & 0.01890 & 0.01059 & $4.940 \cdot 10^{-5}$ & $4.417 \cdot 10^{-3}$ \\
\hline 9 & 0.02558 & 0.01319 & $7.153 \cdot 10^{-5}$ & $5.243 \cdot 10^{-3}$ \\
\hline 10 & 0.03342 & 0.01628 & $1.009 \cdot 10^{-4}$ & $6.188 \mathrm{v}$ \\
\hline 15 & 0.09899 & 0.04009 & $4.053 \cdot 10^{-4}$ & 0.01307 \\
\hline 20 & 0.22987 & 0.08488 & $1.199 \cdot 10^{-3}$ & 0.02492 \\
\hline 25 & 0.43956 & 0.15700 & $2.835 \cdot 10^{-3}$ & 0.04361 \\
\hline 30 & 0.75463 & 0.26319 & $5.771 \cdot 10^{-3}$ & 0.07083 \\
\hline 35 & 1.1996 & 0.41114 & 0.01060 & 0.10834 \\
\hline 40 & 1.7883 & 0.60812 & 0.01801 & 0.15796 \\
\hline 45 & 2.5212 & 0.85969 & 0.02872 & 0.22143 \\
\hline 50 & 3.3878 & 1.1691 & 0.04344 & 0.30023 \\
\hline 60 & 5.5165 & 1.9657 & 0.08746 & 0.50806 \\
\hline 70 & 8.2250 & 3.0125 & 0.15572 & 0.78802 \\
\hline 80 & 11.410 & 4.3142 & 0.25355 & 1.1448 \\
\hline 90 & 14.946 & 5.8594 & 0.38509 & 1.5806 \\
\hline 100 & 18.718 & 7.6277 & 0.55325 & 2.0952 \\
\hline 110 & 22.640 & 9.5947 & 0.75995 & 2.6861 \\
\hline 120 & 26.646 & 11.736 & 1.0063 & 3.3499 \\
\hline 130 & 30.689 & 14.028 & 1.2930 & 4.0823 \\
\hline 140 & 34.730 & 16.451 & 1.6201 & 4.8785 \\
\hline 150 & 38.738 & 18.984 & 1.9875 & 5.7339 \\
\hline 160 & 42.685 & 21.610 & 2.3946 & 6.6436 \\
\hline 170 & 46.550 & 24.314 & 2.8409 & 7.6032 \\
\hline 180 & 50.314 & 27.082 & 3.3253 & 8.6082 \\
\hline 190 & 53.960 & 29.901 & 3.8468 & 9.6545 \\
\hline 200 & 57.478 & 32.759 & 4.4041 & 10.738 \\
\hline 210 & 60.859 & 35.645 & 4.9959 & 11.855 \\
\hline 220 & 64.098 & 38.552 & 5.6208 & 13.003 \\
\hline 230 & 67.193 & 41.470 & 6.2774 & 14.177 \\
\hline 240 & 70.144 & 44.392 & 6.9642 & 15.375 \\
\hline
\end{tabular}




$\begin{array}{lllll}250 & 72.951 & 47.313 & 7.6798 & 16.594 \\ 260 & 75.619 & 50.227 & 8.4227 & 17.832 \\ 270 & 78.150 & 53.129 & 9.1917 & 19.085 \\ 273.15 & 78.920 & 54.040 & 9.4391 & 19.483 \\ 280 & 80.551 & 56.015 & 9.9853 & 20.353 \\ 290 & 82.826 & 58.881 & 10.802 & 21.632 \\ 298.15 & 84.591 & 61.201 & 11.485 & 22.682 \\ 300 & 84.980 & 61.726 & 11.641 & 22.921\end{array}$




\section{Figure Captions}

Figure 1. XRD patterns of all alumina samples.

Figure 2. TGA data showing the mass loss as temperatures increased for all alumina samples.

Figure 3. Plot of the molar heat capacity at constant pressure as a function of temperature for $\gamma$ $\mathrm{Al}_{2} \mathrm{O}_{3}$ with $\mathrm{Al}_{2} \mathrm{O}_{3} \cdot 1.540 \mathrm{H}_{2} \mathrm{O}$ represented by black circles, $\mathrm{Al}_{2} \mathrm{O}_{3} \cdot 0.811 \mathrm{H}_{2} \mathrm{O}$ by red inverted triangles, $\mathrm{Al}_{2} \mathrm{O}_{3} \cdot 0.537 \mathrm{H}_{2} \mathrm{O}$ by green squares, and $\mathrm{Al}_{2} \mathrm{O}_{3} \cdot 0.204 \mathrm{H}_{2} \mathrm{O}$ by yellow diamonds. The inset shows the data at low temperatures $(T<10 \mathrm{~K})$. Included behind the data points are the fit functions for the samples

Figure 4. Plot of the percent deviations of the fit functions for samples AIP 300 from the heat capacity data against temperature. Inset shows deviations below $10 \mathrm{~K}$.

Figure 5. Plot of the percent deviations of the fit functions for samples AIP 600 from the heat capacity data against temperature on a logarithmic scale. Inset shows deviations below $10 \mathrm{~K}$.

Figure 6. Plot of the percent deviations of the fit functions for samples AIP 900 from the heat capacity data against temperature. Inset shows deviations below $10 \mathrm{~K}$.

Figure 7. Plot of the percent deviations of the fit functions for samples AIP 1100 from the heat capacity data against temperature. Inset shows deviations below $10 \mathrm{~K}$.

Figure 8. Plot of the calculated molar heat capacity at constant pressure as a function of temperature for $\mathrm{H}_{2} \mathrm{O}$ adsorbed onto the $\gamma-\mathrm{Al}_{2} \mathrm{O}_{3}$ samples alongside the molar heat capacity of hexagonal ice. Smoothed heat capacity values for the samples with less moles of water adsorbed to their surfaces were subtracted from samples with more moles water adsorbed to their surfaces and were normalized by dividing by the difference in the moles of water. The inset shows the data at low temperatures $(T<10 \mathrm{~K})$. 
Figure 1.

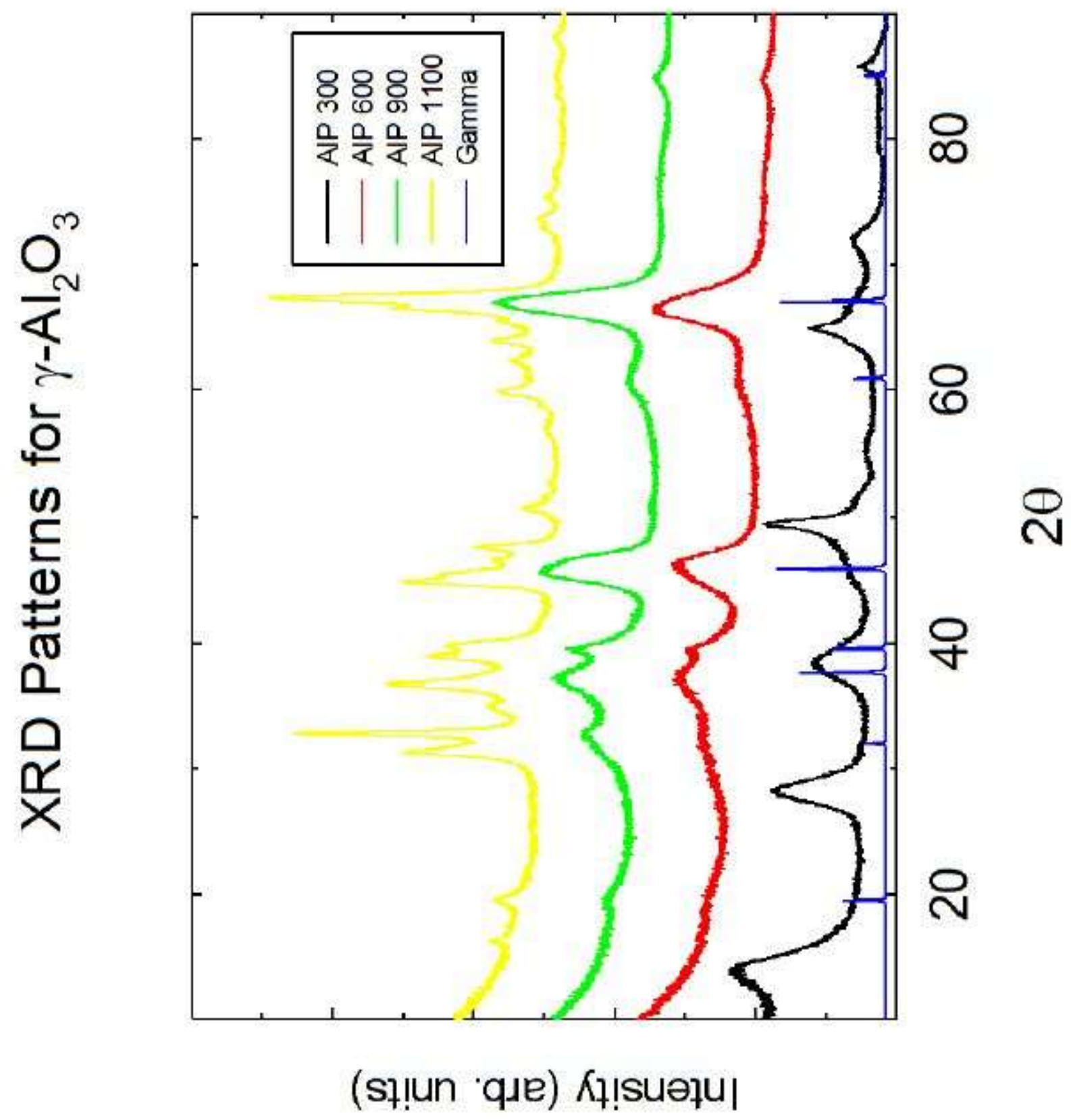


Figure 2.

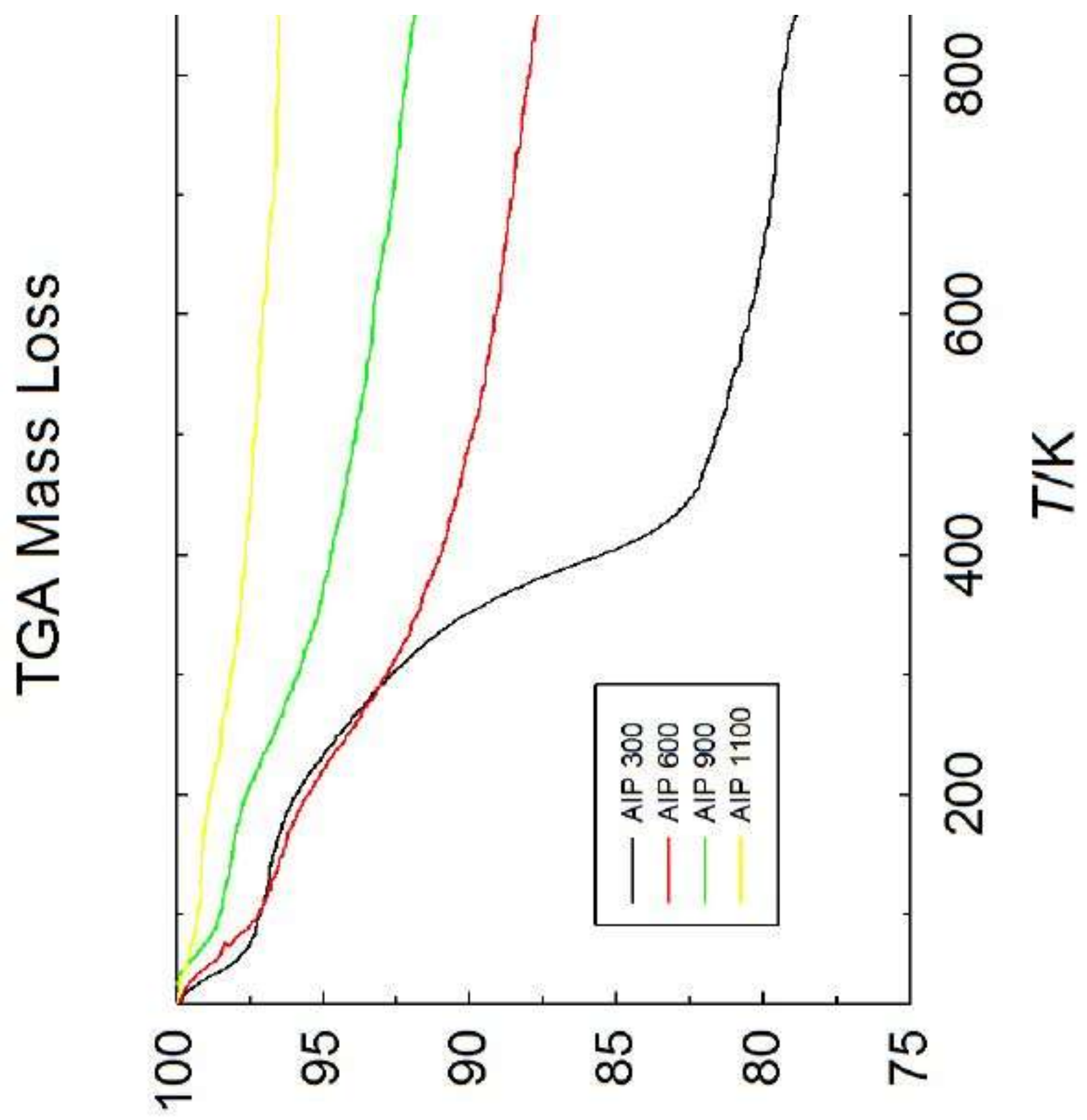


Figure 3.

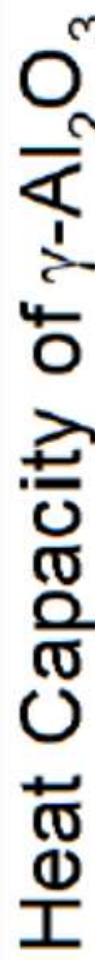

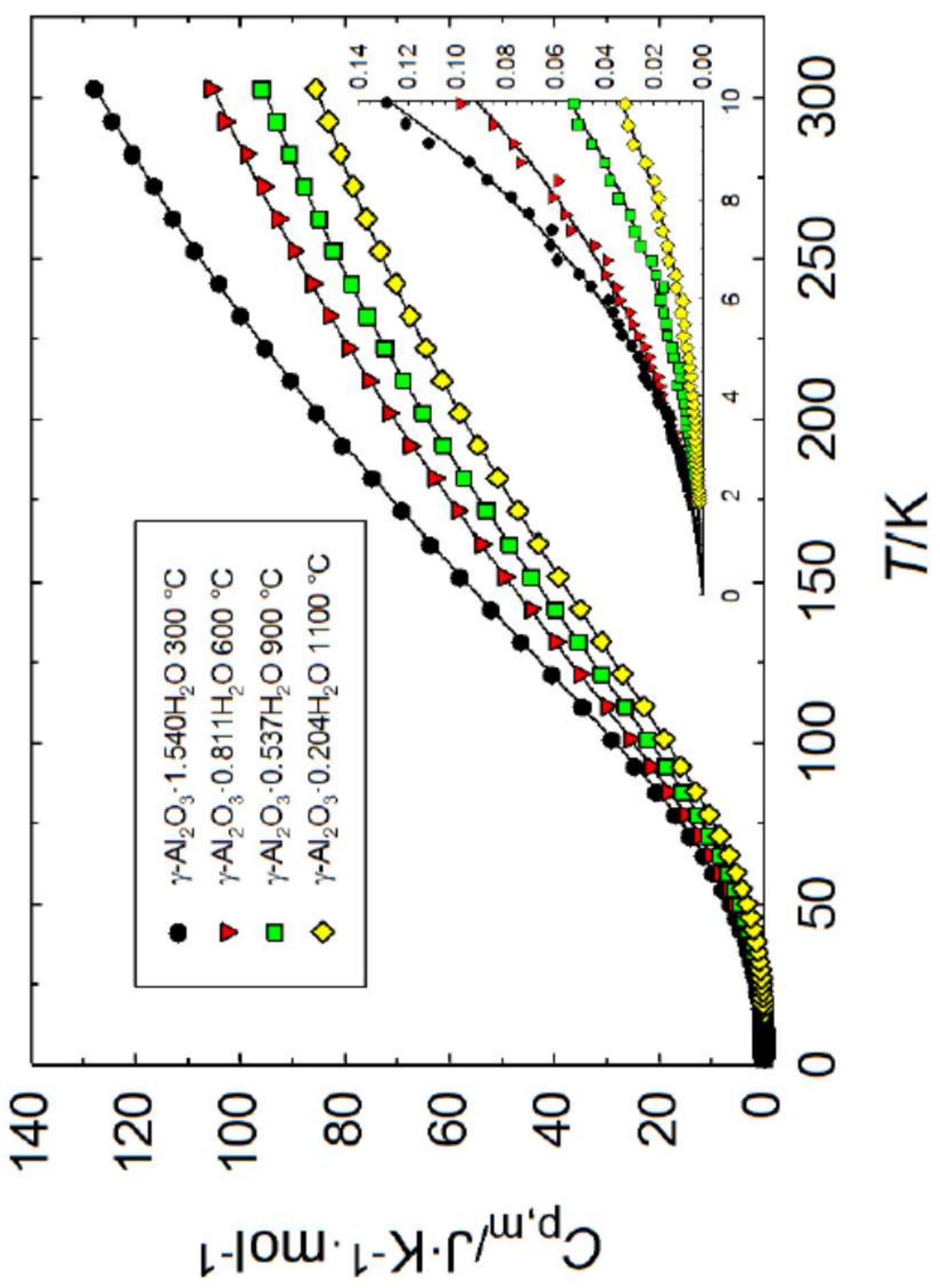


Figure 4.

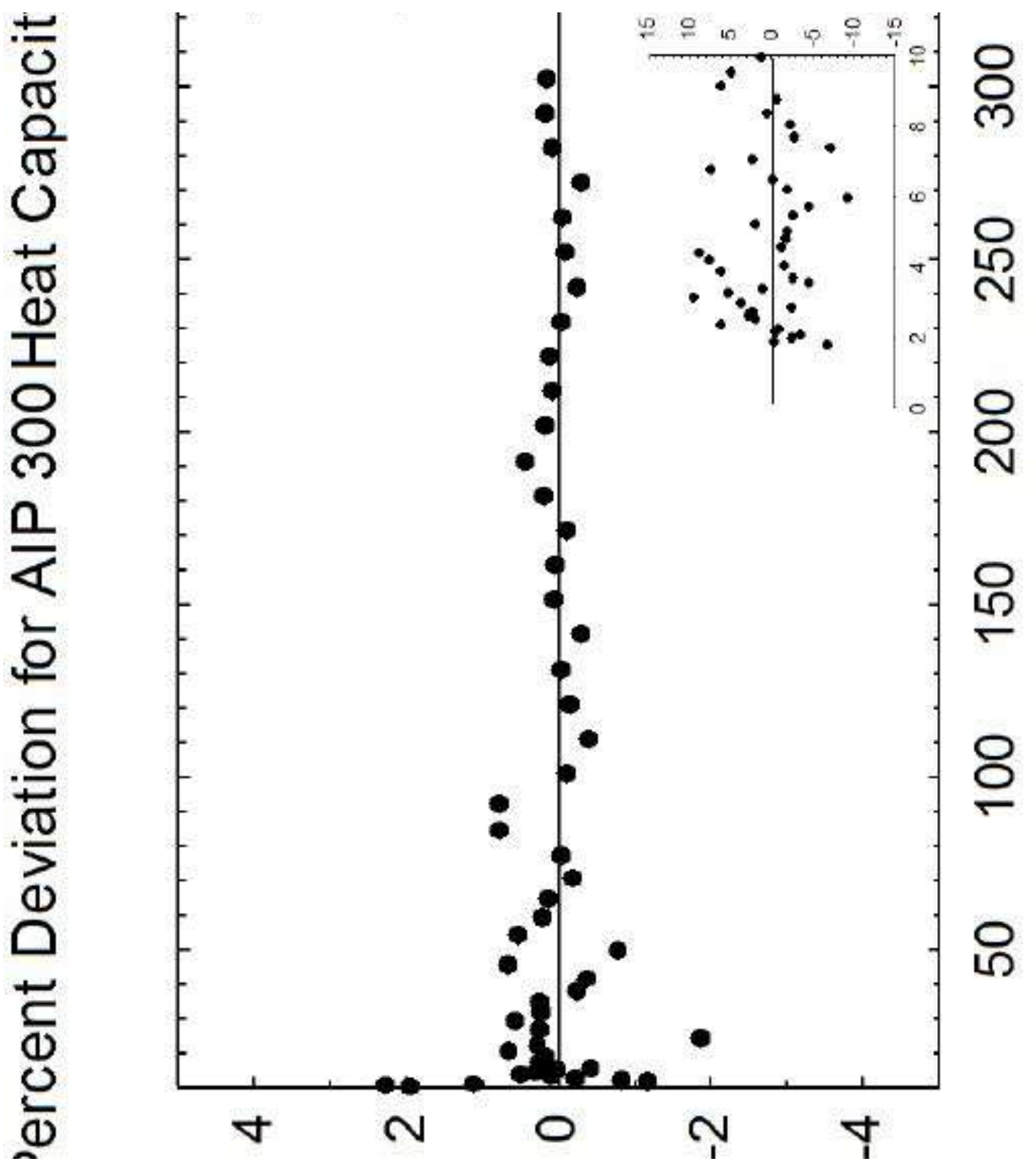


Figure 5.

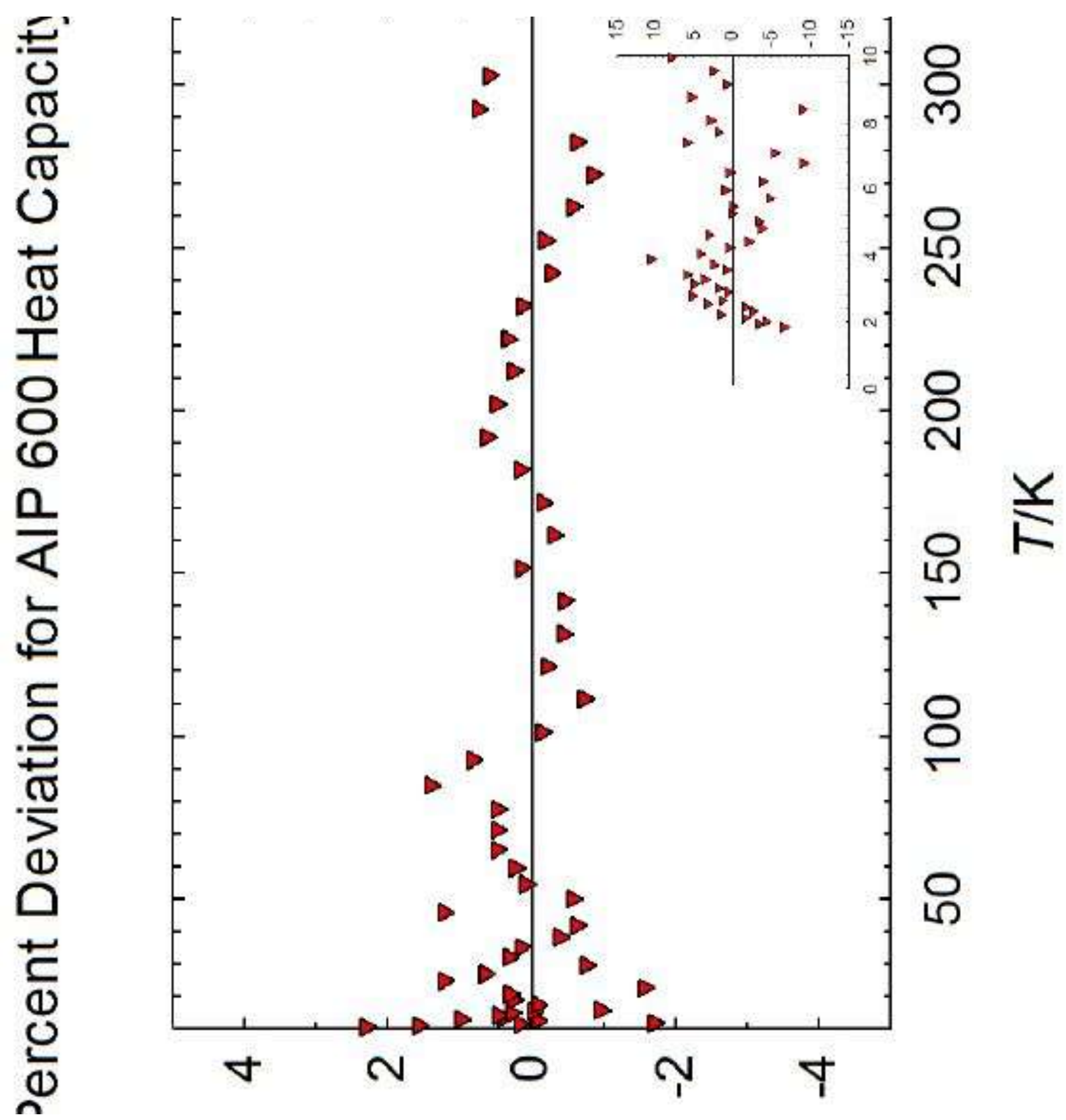


Figure 6.

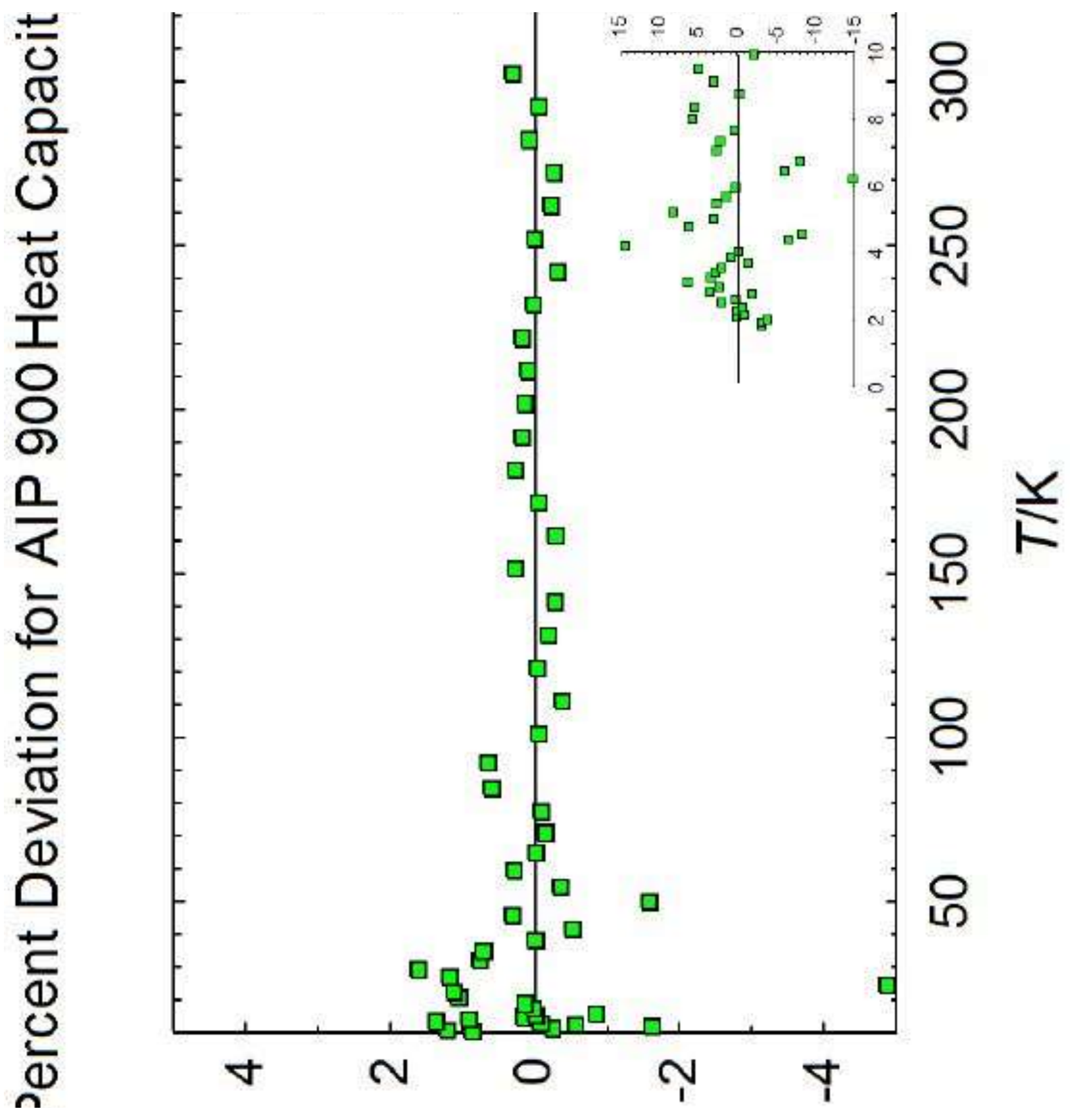


Figure 7.

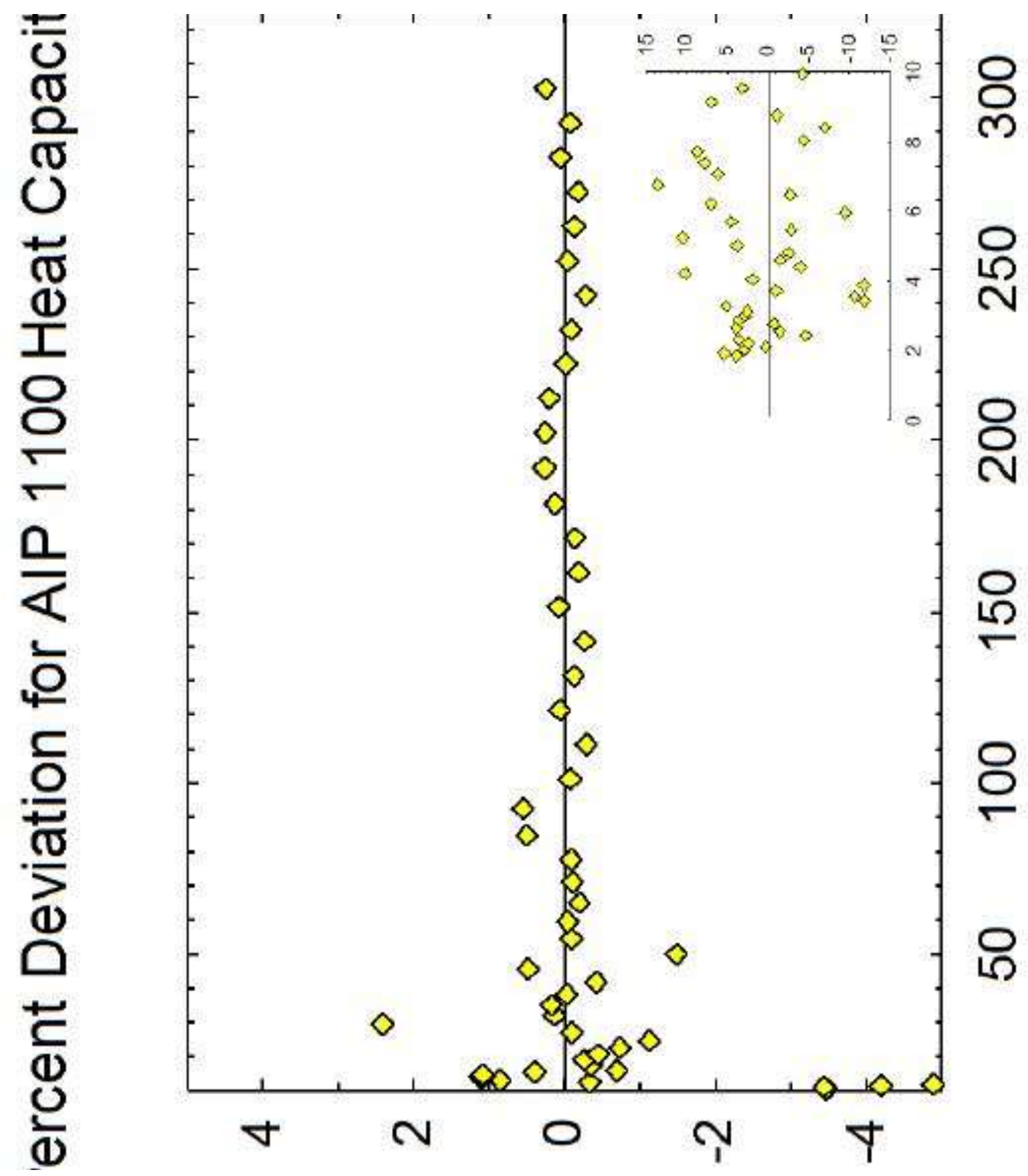


Figure 8.

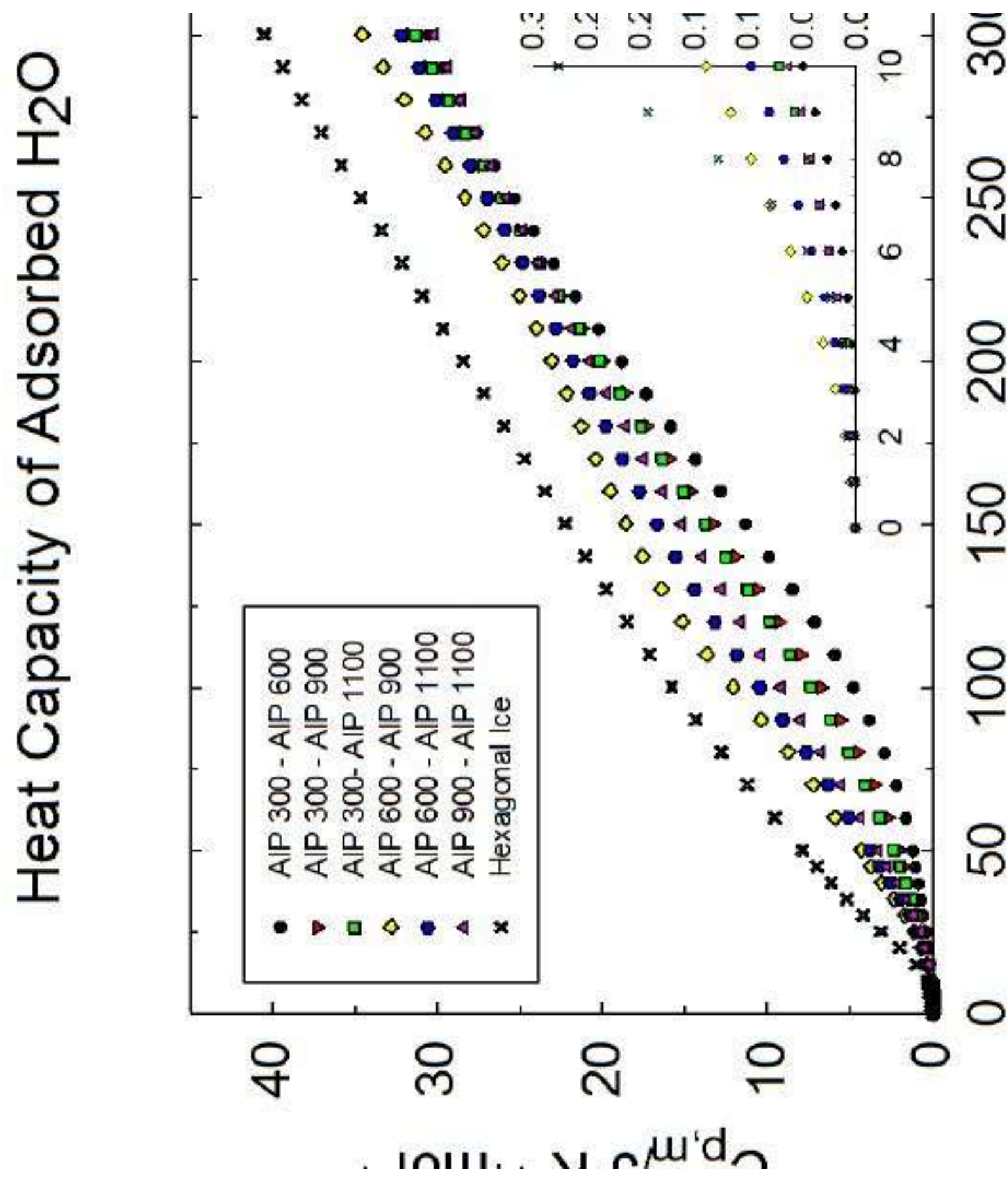

